\title{
Enhancement of sodium/iodide symporter expression in thyroid and breast cancer
}

\author{
T Kogai, K Taki ${ }^{1}$ and $G$ A Brent
}

Molecular Endocrinology Laboratory, VA Greater Los Angeles Healthcare System, Departments of Medicine and Physiology, David Geffen School of Medicine at UCLA, Los Angeles, California 90073, USA

${ }^{1}$ Third Department of Medicine, Yamanashi University, Yamanashi 409-3898, Japan

(Requests for offprints should be addressed to G A Brent; Email: gbrent@ @cla.edu)

\begin{abstract}
The sodium/iodide symporter (NIS) mediates iodide uptake in the thyroid gland and lactating breast. NIS mRNA and protein expression are detected in most thyroid cancer specimens, although functional iodide uptake is usually reduced resulting in the characteristic finding of a 'cold' or non-functioning lesion on a radioiodine image. lodide uptake after thyroid stimulating hormone (TSH) stimulation, however, is sufficient in most differentiated thyroid cancer to utilize $\beta$-emitting radioactive iodide for the treatment of residual and metastatic disease. Elevated serum $\mathrm{TSH}$, achieved by thyroid hormone withdrawal in athyreotic patients or after recombinant human thyrotropin administration, directly stimulates NIS gene expression and/or NIS trafficking to the plasma membrane, increasing radioiodide uptake. Approximately $10-20 \%$ differentiated thyroid cancers, however, do not express the NIS gene despite TSH stimulation. These tumors are generally associated with a poor prognosis. Reduced NIS gene expression in thyroid cancer is likely due in part, to impaired trans-activation at the proximal promoter and/or the upstream enhancer. Basal NIS gene expression is detected in about $80 \%$ breast cancer specimens, but the fraction with functional iodide transport is relatively low. Lactogenic hormones and various nuclear hormone receptor ligands increase iodide uptake in breast cancer cells in vitro, but TSH has no effect. A wide range of 'differentiation' agents have been utilized to stimulate NIS expression in thyroid and breast cancer using in vitro and in vivo models, and a few have been used in clinical studies. Retinoic acid has been used to stimulate NIS expression in both thyroid and breast cancer. There are similarities and differences in NIS gene regulation and expression in thyroid and breast cancer. The various agents used to enhance NIS expression in thyroid and breast cancer will be reviewed with a focus on the mechanism of action. Agents that promote tumor differentiation, or directly stimulate NIS gene expression, may result in iodine concentration in 'scan-negative' thyroid cancer and some breast cancer.
\end{abstract}

Endocrine-Related Cancer (2006) 13 797-826

\section{Introduction}

The thyroid contains $70-90 \%$ total iodine in the body (9-10 mg; Riggs 1952). The thyroid gland must trap about $60 \mu \mathrm{g}$ iodine/day from the circulation to maintain adequate thyroid hormone production. The sodium/iodide symporter (NIS, or SLC5A5 on the NCBI database; http://www.ncbi.nlm.nih.gov/) is expressed on the basolateral membrane of thyroid follicular cells and mediates the accumulation of iodide from the bloodstream to thyroid follicles (Dai et al. 1996). NIS is a membrane-bound glycoprotein with 13 trans-membrane domains and belongs to the sodium/ solute symporter family (Dohan et al. 2003). In normal thyroid tissue, NIS transports two $\mathrm{Na}^{+}$and one $\mathrm{I}^{-}$ down the $\mathrm{Na}^{+}$ion gradient generated from the activity of $\mathrm{Na}^{+} / \mathrm{K}^{+}$ATPase (Fig. 1). NIS actively transports iodide producing an iodine concentration gradient from the thyroid cell to extracellular fluid greater than 30:1. Ouabain, which inhibits the $\mathrm{Na}^{+} / \mathrm{K}^{+}$ATPase, blocks thyroidal iodide uptake (Eggo et al. 1986, Carrasco 1993). Trapped iodide in the follicular cells is released into the lumen through the apical iodide transporter (AIT or SLC5A8; Rodriguez et al. 2002) and pendrin (SLC26A4, the product of Pendred's syndrome gene; Royaux et al. 2000, Yoshida et al. 2004, Fig. 1). Thyroglobulin (Tg) is localized at the apical membrane 


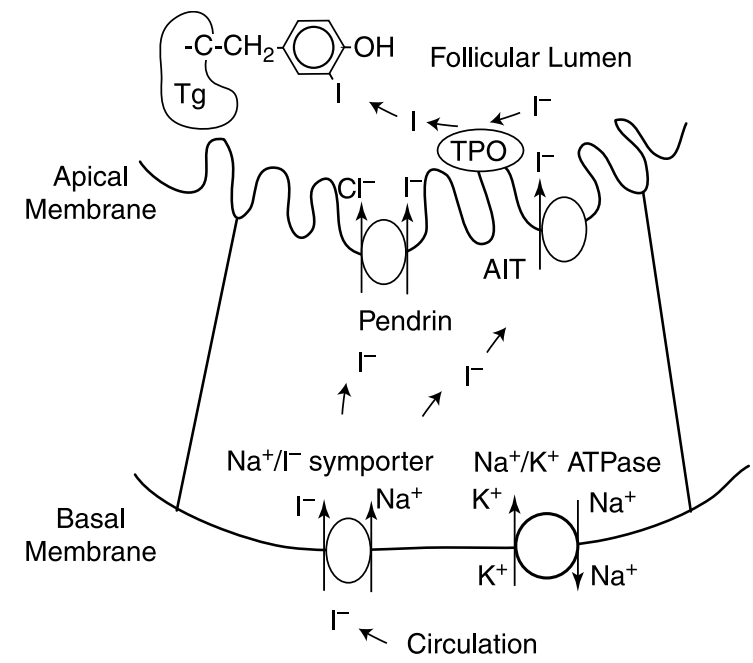

Figure 1 Schematic representation of iodide transport in the thyroid gland.

outside the follicular cells, where internal tyrosyl residues are iodinated by thyroid peroxidase (TPO). The thyroid oxidases (ThOX1 and ThOX2; De Deken et al. 2000) produce oxidative conditions by generation of $\mathrm{H}_{2} \mathrm{O}_{2}$, and are required for the normal function of TPO. Since iodide is bound to an organic compound, this process is known as 'organification' of iodide. Thyrotropin (TSH) increases the expression of genes involved in thyroid iodide metabolism and thyroid hormone synthesis, including NIS, Tg, and TPO (Dunn \& Dunn 2001).

Radioiodide is widely used for the diagnosis and treatment of thyroid disease. Radioiodide is administered orally, absorbed in the stomach and small intestine, and concentrated in thyroid tissues through the action of NIS. Thyroid tissues in benign disease, such as Graves' hyperthyroidism and colloid goiter, and in some differentiated thyroid cancer, organify the trapped radioiodide with $\mathrm{Tg}$, prolonging the biological half-life of the radioiodide. Short half-life, low-energy isotopes, such as ${ }^{123} \mathrm{I}$ and technetium-pertechnetate $\left({ }^{99 \mathrm{~m}} \mathrm{TcO}_{4}^{-}\right)$, are used to image functional thyroid tissue. Longer half-life, high-energy isotopes like ${ }^{131}$ I are used therapeutically to destroy thyroid tissue in both hyperthyroidism and metastatic thyroid cancer after total thyroidectomy. TSH, a pituitary glycoprotein hormone, induces NIS expression in the thyroid (Kogai et al. 1997, Saito et al. 1997, Pekary \& Hershman 1998). The influence of TSH on the stimulation of radioiodide uptake in metastatic thyroid cancer has been recognized, since radioiodine was first used in the 1950s. TSH stimulation is achieved by the cessation of thyroid supplementation after thyroidectomy or exogenous administration of recombinant human TSH (rhTSH). More than $70 \%$ differentiated thyroid cancer concentrates radioiodine after TSH stimulation (Robbins et al. 1991, Schmutzler \& Koehrle 2000, Jarzab et al. 2003). Radioiodide treatment may fully destroy occult micro-carcinoma and is associated with a reduction in the rate of progression of metastatic tumor (Hershman et al. 1995, Schlumberger 1998). Extensive experience with ${ }^{131}$ I treatment of thyroid cancer has demonstrated the importance of maximizing the magnitude of iodide uptake and prolonging the period of radioiodine tumor residence.

Most differentiated thyroid cancer has an excellent prognosis; survival rates are $93-98 \%$ in papillary cancer, and $85-92 \%$ in follicular cancer (Gilliland et al. 1997, Dean \& Hay 2000). Many metastaticdifferentiated thyroid carcinomas, as well as undifferentiated anaplastic cancer, however, do not concentrate sufficient ${ }^{131}$ I for therapy (Maxon \& Smith 1990). In these cases, other therapeutic options, such as surgical removal of metastases (Niederle et al. 1986), external radiation (Kim \& Leeper 1983, Tubiana et al. 1985), or chemotherapy (Kim \& Leeper 1983, Shimaoka et al. 1985, Ain et al. 1996), are utilized, but are largely unsuccessful (Tyler et al. 2000). The correlation between NIS expression in thyroid tumors and their ability to concentrate radioiodine has been confirmed (Caillou et al. 1998, Castro et al. 2001). NIS mRNA expression in papillary thyroid cancer with a poor prognosis is markedly decreased (Ward et al. 2003). The regulation of NIS expression in normal and malignant thyroid cells has been investigated extensively and the various agents that have been recognized to influence expression are summarized (Table 1).

NIS is expressed in extrathyroidal tissues, including; salivary gland, gastric mucosa, mammary gland, ciliary body of the eye, and the choroid plexus (Dohan et al. 2003). Modest iodide uptake is usually detected in the salivary gland, stomach, and intestines during whole body imaging with radioiodide. Lactating breast tissue concentrates a significant amount of iodide as a result of stimulation of NIS expression (Cho et al. 2000, Tazebay et al. 2000). The trapped iodide is secreted in milk and provides iodine for thyroid hormone synthesis to the developing infant (Welcsh \& Mankoff 2000). The lactating breast can concentrate iodide to a similar degree as that seen in the thyroid, producing milk with an iodine concentration of 20-700 $\mu \mathrm{g} / \mathrm{l}$ (Simon et al. 2002b). NIS expression has been demonstrated in more than $80 \%$ breast cancer tissue, although the fraction of tumors that functionally concentrate iodine is likely to be much lower (Tazebay et al. 2000, Wapnir et al. 2003). 
Table 1 NIS expression stimulator in thyroid

\begin{tabular}{|c|c|c|c|c|c|c|}
\hline Agent & Pharmacology & Experimental system & lodide uptake & NIS mRNA & NIS protein & Reference \\
\hline \multirow[t]{7}{*}{ Thyrotropin (TSH) } & TSHR agonist & FRTL-5 rat cell line & $x$ & $x$ & $x$ & Kogai et al. (1997) \\
\hline & & $\mathrm{PCCl} 3$ rat cell line & $x$ & $x$ & & Trapasso et al. (1999) \\
\hline & & WRT rat cell line & & & $x$ & Cass \& Meinkoth (2000) \\
\hline & & $\begin{array}{l}\text { Primary human thyroid cell culture } \\
\text { (normal) }\end{array}$ & $x$ & $x$ & $x$ & $\begin{array}{l}\text { Saito et al. (1997), Ajjan } \\
\text { et al. (1998) }\end{array}$ \\
\hline & & KAT50 human cell line & $x$ & $x$ & & $\begin{array}{l}\text { Venkataraman et al. } \\
\quad \text { (1998) }\end{array}$ \\
\hline & & $\begin{array}{l}\text { Long-term culture of human thyroid } \\
\text { (normal) }\end{array}$ & $x$ & $x$ & $x$ & Kogai et al. (2000b) \\
\hline & & Rat normal thyroid, in vivo & & & $x$ & Levy et al. (1997) \\
\hline $\mathrm{hCG}$ & TSHR agonist & FRTL-5 rat cell line & $x$ & $x$ & $x$ & Arturi et al. (2002) \\
\hline \multirow{3}{*}{ Forskolin } & Adenylyl cyclase activator & FRTL-5 rat cell line & $x$ & $x$ & $x$ & Kogai et al. (1997) \\
\hline & & $\mathrm{PCCl} 3$ rat cell line & & $x$ & & Trapasso et al. (1999) \\
\hline & & $\begin{array}{l}\text { Primary human thyroid cell culture } \\
\text { (normal) }\end{array}$ & $x$ & $x$ & $x$ & Saito et al. (1997) \\
\hline Adenosine & $A_{1}$ receptor agonist & FRTL-5 rat cell line & $x$ & $x$ & $x$ & Harii et al. (1999) \\
\hline tRA & $\begin{array}{l}\text { Retinoic acid receptor } \\
\text { (RAR) agonist }\end{array}$ & $\begin{array}{l}\text { FTC-133 and FTC-238, follicular } \\
\text { cancer cell lines }\end{array}$ & & $\mathrm{x}$ & & Schmutzler et al. (1997) \\
\hline \multirow[t]{2}{*}{ Troglitazone } & PPAR- $\gamma$ ligand & FTC-133, follicular cancer cell line & & $x$ & & Park et al. (2005) \\
\hline & & TPC-1, papillary cancer cell line & & $\mathrm{x}$ & & \\
\hline \multirow[t]{5}{*}{ Depsipeptide } & $\begin{array}{l}\text { Histone deacetylase } \\
\text { (HDAC) inhibitor }\end{array}$ & $\begin{array}{l}\text { FTC-133 and FTC-236, follicular } \\
\text { cancer cell lines }\end{array}$ & $x$ & $x$ & & Kitazono et al. (2001) \\
\hline & & $\begin{array}{l}\text { SW-1736 and KAT-4, anaplastic } \\
\text { cancer cell lines }\end{array}$ & $x$ & $\mathrm{X}$ & & \\
\hline & & BHP 18-21v, papillary cancer cell line & $x$ & $x$ & $x$ & Furuya et al. (2004b) \\
\hline & & BHP18-21v xenograft in vivo & $x$ & & & \\
\hline & & ARO, anaplastic cancer cell line & $\mathrm{x}$ & $\mathrm{X}$ & $x$ & \\
\hline \multirow[t]{5}{*}{ Trichostatin A } & HDAC inhibitor & TPC-1, papillary cancer cell lines & & $x$ & & Zarnegar et al. (2002) \\
\hline & & FTC-133, follicular cancer cell line & & $x$ & & \\
\hline & & XTC-1, Hurthle-cell cancer cell line & & $x$ & & \\
\hline & & BHP18-21v, papillary cancer cell line & & $x$ & $x$ & Furuya et al. (2004b) \\
\hline & & ARO, anaplastic cancer cell line & & $x$ & $\mathrm{x}$ & \\
\hline \multirow[t]{2}{*}{ Valproic acid } & HDAC inhibitor & NPA, papillary cancer cell line & $x$ & $x$ & $x$ & Fortunati et al. (2004) \\
\hline & & ARO, anaplastic cancer cell line & & $x$ & $x$ & \\
\hline 5-Azacytidine & Demethylation agent & $\begin{array}{l}\text { NPA, KAT5, KAT10, papillary cancer } \\
\text { cell lines }\end{array}$ & $x$ & $x$ & & $\begin{array}{l}\text { Venkataraman et al. } \\
\text { (1999) }\end{array}$ \\
\hline \multicolumn{7}{|l|}{ Clinical use } \\
\hline hrTSH & & Metastatic/recurrent cancer (50-90\%) & $x$ & & & $\begin{array}{l}\text { Ladenson et al. (1997), } \\
\text { Jarzab et al. (2003) }\end{array}$ \\
\hline 13-Cis RA & Pro-drug of $t$ RA & Metastatic/recurrent cancer (0-42\%) & $x$ & & & Simon et al. (2002a) \\
\hline
\end{tabular}

$X$ in column indicates significant induction by agent. TSHR, thyroid stimulating hormone receptor. 
Uptake of ${ }^{125} \mathrm{I}$ or ${ }^{99 \mathrm{~m}} \mathrm{Tc}$ in breast cancer has been confirmed by imaging studies (Moon et al. 2001, Upadhyay et al. 2003, Wapnir et al. 2004). The NIS in breast cancer cells can be induced in vitro by lactogenic hormones (Cho et al. 2000, Arturi et al. 2005), insulin (Arturi et al. 2005), and some nuclear receptor ligands, such as retinoids, peroxisome proliferator-activated receptor- $\gamma$ (PPAR- $\gamma$ ) ligands, and glucocorticoids (Kogai et al. 2000b, 2005, Tanosaki et al. 2003, Table 2). The induction of iodide uptake and NIS expression has been confirmed in some mouse breast cancer models (Kogai et al. 2004). Selective cytotoxicity of ${ }^{131}$ I has been demonstrated after in vitro retinoid treatment (Kogai et al. 2000b, 2005). Agents that stimulate NIS expression in breast cancer sufficient to concentrate radioiodide have been considered as a source of potential therapy for some differentiated breast cancer (Daniels \& Haber 2000, Boelaert \& Franklyn 2003).

In this review, we will describe the recent findings describing the mechanism of NIS gene regulation in normal and malignant, thyroid and breast. Agents utilized to directly stimulate NIS gene expression or promote differentiation in thyroid and breast cancer will be discussed. The rapidly expanding field of NIS as a gene therapy tool targeted to a range of malignancies has been previously reviewed (Spitzweg \& Morris 2002), and will be discussed only briefly. The review will focus on agents that promote endogenous NIS expression.

\section{TSH regulation of NIS and other iodide transporters in normal thyroid tissue}

The thyroid follicle has a two-step process of iodide transport to accumulate iodide into the lumen, and three transporters, NIS, AIT (SLC5A8; Rodriguez et al. 2002), and pendrin (SLC26A4; Royaux et al. 2000), mediate the process. NIS on the basolateral membrane of thyroid follicular cells mediates iodide accumulation into the cells from the bloodstream. AIT and pendrin are expressed on the apical membrane (Bidart et al. 2000, Royaux et al. 2000, Rodriguez et al. 2002), and transport the trapped iodide to the lumen (Yoshida et al. 2002, 2004). NIS has a very high affinity for iodide $\left(K_{\mathrm{m}} 20-40 \mu \mathrm{M}\right.$; Weiss et al. 1984b, Mandell et al. 1999, Kogai et al. 2000b), so that thyroid cells can concentrate iodide from the bloodstream up to $2 \mathrm{mM}$ (Yoshida et al. 2002). Pendrin requires a relatively high concentration of iodide (more than $1 \mathrm{mM}$ ) in the cytoplasm to function as an iodide transporter (Yoshida et al. 2004). Iodide efflux by pendrin to the lumen, therefore, likely depends on functional NIS expression.
TSH stimulation of NIS mRNA and protein expression are mediated by the cAMP pathway in rodent cell lines, Fisher rat thyroid cell line (FRTL)-5 cells (Weiss et al. 1984a, Kogai et al. 1997), PC Cl3 immortalized rat thyroid cells (Trapasso et al. 1999), and human primary thyroid cells (Saito et al. 1997, Kogai et al. 2000a). The upregulation of NIS in response to TSH is at both the transcriptional and the post-translational levels. TSH stimulates the NIS promoter and NIS upstream enhancer (NUE; Endo et al. 1997, Ohmori et al. 1998, Ohno et al. 1999, Taki et al. 2002), increases the half-life of the NIS protein, and stimulates the trafficking of the NIS to the plasma membrane (Riedel et al. 2001). Direct stimulation of the TSH receptor in Graves' disease by antibody (Saito et al. 1997, Caillou et al. 1998, Jhiang et al. 1998, Castro et al. 1999, Lazar et al. 1999), constitutive activating mutations of the TSH receptor in a hyperfunctioning thyroid adenoma (Mian et al. 2001), or the weak agonist human chorionic gonadotropin (hCG; Hershman 1999, Arturi et al. 2002), activate the cAMP pathway and result in marked NIS expression. In contrast, the expression of AIT is not increased in hyperfunctioning thyroid adenomas or Graves' disease (Lacroix et al. 2004, Porra et al. 2005). The expression of pendrin protein is increased in hyperfunctioning thyroid tissues, possibly due to post-transcriptional upregulation by TSHR signaling (Bidart et al. 2000, Mian et al. 2001). Iodide transport in the thyroid gland is regulated by TSH, primarily through the stimulation of NIS expression.

\section{Transcriptional regulation of NIS by TSH in normal thyroid cells}

Recent progress from sequencing of human and rat genomes has allowed comparison of the NIS coding and regulatory gene sequence from various species. Since TSH stimulates NIS expression in both human and rodent thyroid cells, the regulatory region(s) for NIS induction by TSH was expected to be in sequences common to human and rat NIS genes. The human NIS gene maps to 19p13.2-p12 (Smanik et al. 1997) and contains 14 introns in 22116 bases as measured from the first to the last exon. The rat NIS gene is markedly smaller in size compared with human (9260 bases), although the number of exons is the same and the size of mRNA is similar. The next gene upstream of NIS on the human genomic sequence, ribosomal protein L18a (RPL18a), is located 8657 bases upstream from the first exon of NIS, while the distance on the rat genome is only 2130 bases (Fig. 2A). The similarity of the $5^{\prime}$ flanking region (from the NIS-coding sequence to the RPL18a-coding sequence) between human and rat is only $11.8 \%$. 
Table 2 NIS expression stimulator in breast tissues

\begin{tabular}{|c|c|c|c|c|c|c|}
\hline Agent & Experimental system & lodide uptake ${ }^{a}$ & NIS mRNA & NIS protein & References & Note \\
\hline \multirow[t]{2}{*}{ Oxytocin } & Rat normal breast, in vivo & $x$ & & $x$ & $\begin{array}{l}\text { Cho et al. (2000), Tazebay } \\
\text { et al. (2000) }\end{array}$ & $\mathrm{E}_{2}$ required \\
\hline & Cancer primary culture (3-D) & & $\mathrm{X}$ & & Cho et al. (2000) & \\
\hline \multirow[t]{4}{*}{ Prolactin } & Rat normal breast, in vivo & $x$ & & $x$ & $\begin{array}{l}\text { Cho et al. (2000), Tazebay } \\
\text { et al. (2000) }\end{array}$ & $E_{2}$ required \\
\hline & Mouse breast explant & $\mathrm{X}$ & & $x$ & Rillema et al. (2000) & \\
\hline & Cancer primary culture (3D) & & $x$ & & Cho et al. (2000) & \\
\hline & MCF-7, ER + cancer cell line & $\sim 10^{\mathrm{b}}$ & $\mathrm{X}$ & $\mathrm{X}$ & Arturi et al. (2005) & \\
\hline Estradiol & Rat normal breast, in vivo & $X$ & & $x$ & Tazebay et al. (2000) & \\
\hline 8-Bromo-cAMP, cholera toxin & MCF-7, ER + cancer cell line & $\sim 3.3^{b}$ & $x$ & & $\begin{array}{l}\text { Knostman et al. (2004), Arturi } \\
\text { et al. }(2005)^{\mathrm{b}}\end{array}$ & \\
\hline hCG & MCF-7, ER + cancer cell line & $\sim 3.0^{\mathrm{c}}$ & & & Knostman et al. (2004) & \\
\hline Prostaglandin $E_{2}$ & MCF-7, ER + cancer cell line & $\sim 2.3^{\mathrm{C}}$ & & & Knostman et al. (2004) & \\
\hline $\begin{array}{l}\text { Insulin/insulin-like growth factor } \\
\text { (IGF)-I/IGF-II }\end{array}$ & MCF-7, ER + cancer cell line & $11-14^{\mathrm{b}}$ & $x$ & & Arturi et al. (2005) & \\
\hline \multirow[t]{3}{*}{ All-trans RA (tRA) } & MCF-7, ER + cancer cell line & $\sim 9.2^{d}$ & $x$ & $\mathrm{x}$ & Kogai et al. $(2000 b, 2005)$ & \\
\hline & MCF-7 xenograft in vivo & $x$ & $\mathrm{X}$ & $\mathrm{X}$ & Kogai et al. (2004) & \\
\hline & MMTV-PyVT in vivo & $\mathrm{x}$ & $\mathrm{X}$ & & Kogai et al. (2004) & \\
\hline Dex + RA & MCF-7, ER + cancer cell line & $12-18^{\mathrm{e}}$ & $x$ & & Kogai et al. (2005) & Synergistic effect with RA \\
\hline AGN190168 (RAR $\beta / \gamma$ ligand) & MCF-7, ER + cancer cell line & $\sim 9.3^{f}$ & $\mathrm{X}$ & & Kogai et al. (2005) & Long duration \\
\hline AGN194433 (RAR $\gamma$ agonist) & MCF-7, ER + cancer cell line & $\sim 4.0^{f}$ & & & Kogai et al. (2005) & \\
\hline $\begin{array}{l}\text { AGN197496, } 195183 \text { (retinoic } \\
\text { acid receptor } \alpha \text { ligands) }\end{array}$ & MCF-7, ER + cancer cell line & $\sim 3.0^{g}, \sim 3.3^{f}$ & $x$ & & $\begin{array}{l}\text { Tanosaki et al. }(2003)^{g} \text {, Kogai } \\
\text { et al. }(2005)^{f}\end{array}$ & \\
\hline $\begin{array}{l}\text { AGN195203, 194204, } 196060 \\
\text { (retinoid X receptor ligands) }\end{array}$ & MCF-7, ER + cancer cell line & $\sim 2.5^{\mathrm{g}}, \sim 6.0^{\mathrm{f}}$ & $x$ & & $\begin{array}{l}\text { Tanosaki et al. }(2003)^{\mathrm{g}} \text {, Kogai } \\
\quad \text { et al. }(2005)^{\mathrm{f}}\end{array}$ & \\
\hline \multirow[t]{3}{*}{ 9-Cis RA } & MCF-7, ER + cancer cell line & $\sim 14^{\mathrm{g}}, \sim 9.0^{\mathrm{d}}$ & $x$ & & $\begin{array}{l}\text { Tanosaki et al. }(2003)^{\mathrm{g}} \text {, Kogai } \\
\text { et al. }(2005)^{\mathrm{d}}\end{array}$ & \\
\hline & T47D, ER + cancer cell line & & $x$ & & Tanosaki et al. (2003) & \\
\hline & BT474, ER + cancer cell line & & $x$ & & Tanosaki et al. (2003) & \\
\hline Troglitazone (PPAR- $\gamma$ ligand) + & MCF-7, ER + cancer cell line & $\sim 9.6^{\mathrm{h}}$ & $\mathrm{X}$ & & Tanosaki et al. (2003) & Synergistic effect with RA \\
\hline
\end{tabular}

$X$ in column indicates significant induction by agent.

${ }^{a}$ Fold induction compared to without treatment is shown for data from MCF-7 cells.

'The induction at $12 \mathrm{~h}$. Cells were maintained in Dulbecco's Modified Eagle's Medium (DMEM) with $0.2 \%$ fetal bovine serum (FBS).

${ }^{\mathrm{c}}$ The induction at $24 \mathrm{~h}\left(\mathrm{PGE}_{2}\right)$ or $48 \mathrm{~h}(\mathrm{hCG})$. Cells were maintained in DMEM: F12, 50: 50 with 10\% FBS.

${ }^{\mathrm{d}}$ The duration is $36-72 \mathrm{~h}$. Cells were maintained in Minimum essential medium (MEM) with $10 \%$ FBS or serum replacement.

${ }^{\mathrm{e}}$ The duration is $2-4$ days with $10^{-7} \mathrm{M}$ tRA or 2-5 days with $10^{-6} \mathrm{M}$ AG190168. Cells were maintained in MEM with $10 \%$ FBS or serum replacement.

${ }^{\mathrm{f}}$ The induction at $48 \mathrm{~h}$. Cells were maintained in MEM with $10 \%$ FBS or serum replacement.

9The induction at $24 \mathrm{~h}$.

${ }^{\mathrm{h}}$ The induction at $24 \mathrm{~h}$ with $10^{-7} \mathrm{M}$ 9-cis RA. 
(A)

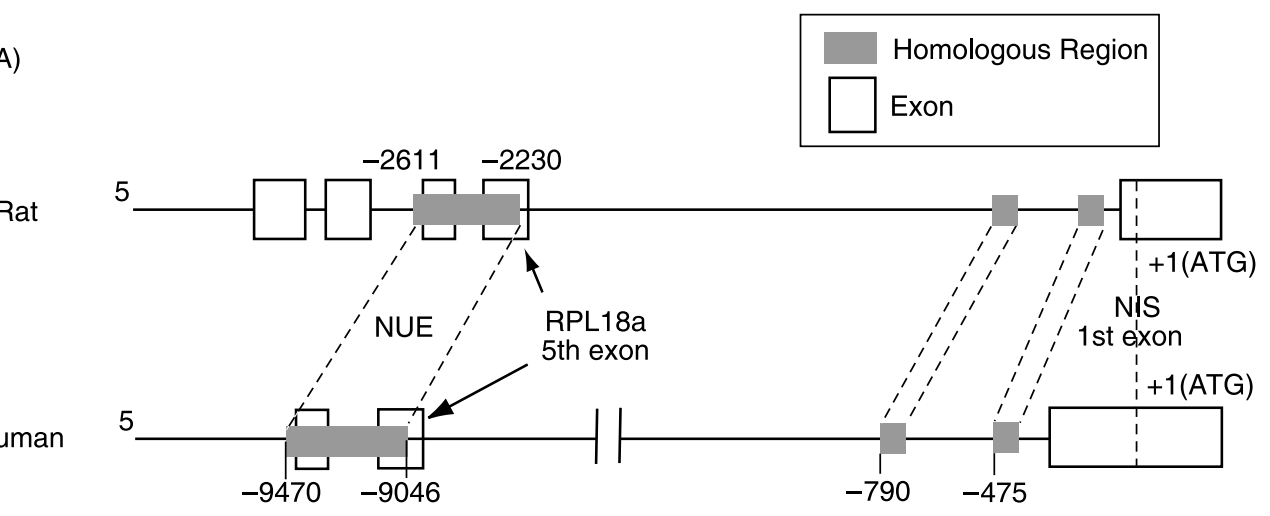

(B)

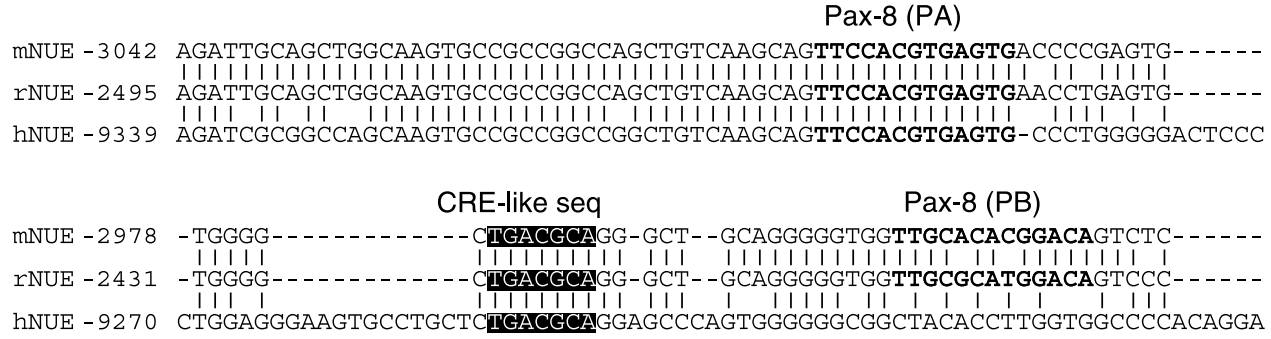

Figure 2 Comparison of the human and rat sodium/iodide symporter (NIS) gene. (A) Three homologous regions (more than $60 \%$ homology) in the $5^{\prime}$-flanking region are shown. (B) Comparison of the NIS upstream enhancer (NUE) sequences of human and rodents. A Pax-8 element (PB) is missing on the human NUE.

The basal promoter of the human NIS gene $(-475$ to -393$)$ has a strong similarity $(72 \%)$ with the rat promoter ( -196 to -114 ; Fig. $2 \mathrm{~A}$ ). The human sequence between -790 and -728 also has some similarity $(63.5 \%)$ with the rat sequence between -422 and -361 , although no functional regulatory elements have been characterized. The NUE is a strong TSH-responsive enhancer, located between -9470 to -9046 on the human NIS (Taki et al. 2002) and -2611 to -2230 on the rat NIS (Ohno et al. 1999), with about $70 \%$ homology between these species.

These regulatory regions contain putative ciselements for thyroid-selective transcription factors, Pax-8 (a paired domain containing transcription factor) and thyroid transcription factor-1 (TTF-1 or Nkx-2.1, a homeo-domain containing transcription factor), both of which are required for thyroid development and differentiation (De Felice \& Di Lauro 2004). The NIS gene promoter/enhancer is regulated by these transacting factors although with some variation among species (Endo et al. 1997, Ohmori et al. 1998, Ohno et al. 1999, Taki et al. 2002). The NUE requires Pax-8 and cAMP-responsive element binding protein (CREB) for its full activity (Ohno et al. 1999, Taki et al. 2002). CREB is one of the basic-leucine zipper (B-ZIP) transcription factor, containing a leucine zipper domain, which mediates DNA binding and dimerization to form homodimers or heterodimers with other B-ZIP proteins (Vinson et al. 2002). A participation of other B-ZIP proteins, such as c-Fos, c-Jun, and the activating transcription factor-2 (ATF-2), may play a role in NUE activation (Chun et al. 2004).

\section{Regulation of the NIS proximal promoter}

The core promoter region of the NIS gene contains a TATA-like motif (AATAAAT) and a GC box (CCCGCCCC). Binding of $\mathrm{Sp}-1$ and an 'Sp-1-like' protein to the GC-box has been demonstrated, and is required for full activity of the NIS basal promoter $(\mathrm{Xu}$ et al. 2002). The rat NIS proximal promoter contains two cis-elements for thyroid-specific transcription factors, TTF-1 between -245 and -230 (Endo et al. 1997) and NIS TSH-responsive factor-1 (NTF-1) around -405 (Ohmori et al. 1998). TSH/cAMP-induced upregulation of the rat NIS gene expression requires NTF-1, which also contributes to TTF-1-mediated thyroid-specific NIS gene expression (Ohmori et al. 1998). The binding of NTF-1 to the cis-element is diminished by an oxidizing agent, diamide, and restored by the reducing agent dithiothreitol, suggesting oxidation/reduction (redox) 
state regulation of NTF-1 (Ohmori et al. 1998). The human NIS 5'-flanking region contains two putative NTF-1 sites with a consensus sequence, GNNCGGANG, located -558 to -550 (one base mismatch) and -439 to -430 (two base mismatch; Kogai et al. 2001).

\section{Characterization of the NUE}

The NUE responds strongly to TSH and cAMP stimulation in thyroid cells (Ohno et al. 1999, Schmitt et al. 2002, Taki et al. 2002, Lin et al. 2004). In the rodent NIS gene, the NUE contains two Pax-8 elements (PA and PB, see Fig. 2B). A cAMP-responsive element (CRE)-like sequence (TGACGCA) is located between the two Pax-8 elements (Ohno et al. 1999, Lin et al. 2004). In the human NUE, one of the Pax- 8 elements downstream of the CRE is missing (Schmitt et al. 2002, Taki et al. 2002), reducing sequence similarity between human and rodent to about $70 \%$ (Fig. 2B). Our mutagenesis study of these elements indicated that both the Pax- 8 element and the CRE-like sequence, but not the TTF-1 element, are required for NUE activity (Taki et al. 2002). TSH and cAMP agonists significantly activate the NUE through the Pax-8 element and the CRE-like sequence in human and rodent cells (Ohno et al. 1999, Taki et al. 2002).

\section{Redox state regulation of the NIS promoter}

The redox state regulates a number of cellular responses by modifying the status of redox-sensitive cysteine residues on signal transduction molecules and transcription factors. Some NIS gene regulatory factors, such as Pax-8 (Puppin et al. 2004), rat TSH-responsive factor NTF-1 (Ohmori et al. 1998), and p38-mitogenactivated protein kinase (MAPK; Pomerance et al. 2000), are regulated by redox state. TSH stimulates the reduction of Pax-8 and binding to the cis-element in thyroid cells (Kambe et al. 1996). TSH increases the expression of redox factor-1 (Ref-1, also called apurinic apyrimidinic endonuclease, APE; Asai et al. 1997), a nuclear enzyme mediating reduction of transcription factors (Nakamura et al. 1997, Rothwell et al. 1997), as well as the translocation of Ref-1 into the nucleus (Tell et al. 2000). Ref-1 stimulates Pax-8 DNA binding in thyroid cells (Tell et al. 1998a,b).

\section{Signal transduction of the NUE in thyroid}

TSH stimulates the NUE in thyroid cells through the cAMP pathway (Ohno et al. 1999, Schmitt et al. 2002, Taki et al. 2002, Lin et al. 2004). TSHR is a guanine nucleotide-binding protein (G-protein) coupled receptor and activates adenylyl cyclase through stimulatory $\mathrm{G}$ protein (Gs protein) to generate cAMP.
An adenylyl cyclase agonist, forskolin, increases cAMP accumulation and activates the NUE in thyroid cells, mimicking the TSHR stimulation (Ohno et al. 1999, Taki et al. 2002). cAMP activates both protein kinase-A (PKA)-dependent pathways and PKA-independent pathways in thyroid cells. These pathways include PKA-CREB, APE/Ref-1-Pax-8, and two of three major MAPK pathways, the extracellular signalregulated kinase (ERK) MAPK pathway and the p38 MAPK pathway (Fig. 3).

Chronic TSH stimulation of FRTL-5 cells downregulates a catalytic subunit of PKA and leads to a lack of response of the CRE to further cAMP stimulation (Armstrong et al. 1995). Treatment with forskolin after chronic TSH stimulation, therefore, determines whether a cAMP pathway to a CRE is dependent on PKA or not. We have observed that forskolin stimulates the NUE even after chronic TSH stimulation without endogenous PKA, while overexpression of exogenous PKA increases the NUE activity without cAMP stimulation by forskolin (Taki et al. 2002). These results indicate that both PKA-dependent and -independent pathways are involved in the stimulation of NUE.

Members of the Ras superfamily (Rho family) of small guanosine triphosphate (GTP)-binding proteins are involved in the regulation of cell growth, differentiation, cytoskeletal reorganization, and protein kinase activation. Rap1 (Tsygankova et al. 2001) and Rac1 (Pomerance et al. 2000), Ras family members, have been reported mediators of TSH-stimulated NIS expression in thyroid cells.

In mammalian cells, guanine-nucleotide-exchange factors (GEFs) positively regulate small GTP-binding proteins in response to a variety of signals. GEFs catalyze the dissociation of GDP from the inactive GTP-binding proteins. GTP can then bind and induce structural changes that allow interaction with effectors. Some GEFs bind to cAMP and are directly activated by cAMP (cAMP-GEFs; Kawasaki et al. 1998, de Rooij et al. 2000). Some investigators have reported that TSH upregulates Rap1 in a PKA-independent manner in thyroid cells (Dremier et al. 2000, Iacovelli et al. 2001, Tsygankova et al. 2001). Rap1 is one of the effectors of cAMP-GEFs, suggesting the possibility that TSH/cAMP regulates Rap1 through cAMP-GEFs. On the other hand, PKA activates Rap1 by phosphorylation in mammalian cells (Hata et al. 1991, Altschuler et al. 1995). The Rap1, therefore, is regulated by both cAMP-GEFs and PKA, and this dual regulation likely brings about the PKA-dependent and -independent pathways in thyroid cells.

Rap1 may contribute to TSH induction of NIS expression in FRTL-5 rat thyroid cells (Tsygankova 


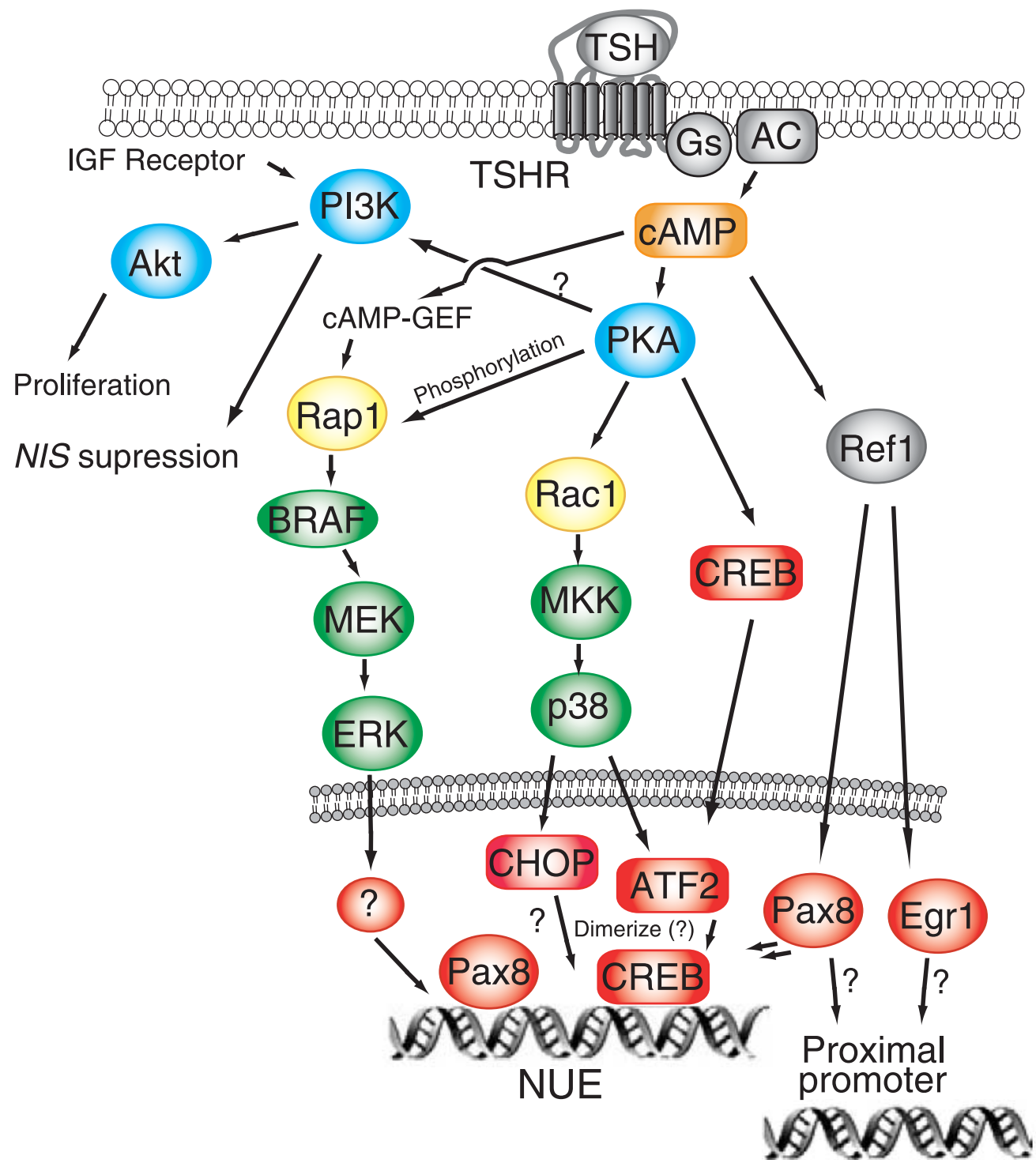

Figure $3 \mathrm{TSH}$ signal transduction to the NIS gene in thyroid cells. CHOP, CCAAT/enhancer binding protein (C/EBP) homologous protein.

et al. 2001), likely through the v-raf murine sarcoma viral oncogene homolog B1 (BRAF) MAP kinase (MEK)1/2-ERK1/2 MAPK pathway (Iacovelli et al. 2001, Taki et al. 2002, Fig. 3). Dominant-negative mutant of Rap1A partially (50\%) inhibits the cAMPinduced NUE activity (Chun et al. 2004). TSH stimulates the MEK1/2-ERK1/2 MAPK pathway in FRTL-5 cells through Rap1 and BRAF without PKA activation (Iacovelli et al. 2001). An inhibitor of MEK1/2, PD98059, partially (43\%) inhibits human NUE activation by forskolin (Taki et al. 2002). In contrast, the activation of the MEK-ERK pathway in response to TSH is not observed in primary dog thyrocytes (Vandeput et al. 2003). The regulation of
NUE by MEK-ERK may vary among different species or cell lines.

Phosphatidylinositol 3-kinase (PI3K) phosphorylates the inositol ring of phosphatidylinositol and related compounds at the $3^{\prime}$-position. These products serve as second messenger-signaling molecules for regulating cell growth and differentiation. The TSH/cAMP stimulation of cell proliferation with insulin-like growth factor-I (IGF-I) is dependent on a small GTP-binding protein Ras and the PI3K in thyroid cells (Cass \& Meinkoth 2000, Coulonval et al. 2000, Saito et al. 2001). Although TSH activates PI3K signaling, PI3K downregulates NIS expression in thyroid cells (Cass \& Meinkoth 2000, Garcia \& 
Santisteban 2002). Expression of a Ras mutant that selectively stimulates PI3K markedly decreases the TSH-induced NIS expression in Wistar rat thyroid (WRT) cells (Cass \& Meinkoth 2000). IGF-I inhibits the cAMP-induced NIS expression in FRTL-5 cells through PI3K activation (Garcia \& Santisteban 2002). An evaluation of the rat NIS gene regulatory sequence has indicated that the region between -1947 and -1152 is responsible for the inhibitory effect of IGF-I (Garcia \& Santisteban 2002).

TSH and cAMP activate another MAPK pathway, MKK3/6-p38 MAPK, through a small GTP-binding protein Rac1 (Pomerance et al. 2000). An inhibitor of the p38 MAPK, SB203580, significantly decreases the cAMP-induced NIS mRNA expression in FRTL-5 cells (Pomerance et al. 2000). The TSH/cAMP stimulates the p38-MAPK phosphorylation PKA-dependently, but not PKC or PI3K (Pomerance et al. 2000). TSH stimulates the phosphorylation of MKK3/6, p38-MAPK, and ATF2, a substrate of the p38 (Pomerance et al. 2000). The ATF-2 has been reported to bind the CRE-like sequence in the rat NUE (Chun et al. 2004). Reactive oxygen species is involved in the activation of p38-MAPK by cAMP (Pomerance et al. 2000), indicating redox regulation of the p38-MAPK pathway in thyroid cells. Another substrate of p38-MAPK, CCAAT/enhancerbinding homologous protein (CHOP), is also involved in the TSH stimulation of the rat NUE (Pomerance et al. 2003), although binding of CHOP to the NUE has not been confirmed.

Some B-ZIP transcription factors, CREB1, ATF1, and/or the cAMP-response element modulator (CREM) , bind to the CRE-like regulatory sequence in the human NUE. These B-ZIP factors form homodimers or heterodimers with other B-ZIP proteins using a leucine zipper (B-ZIP) domain and then bind to these ciselements on the target gene (Vinson et al. 2002). The cAMP-activated PKA phosphorylates the CREB to regulate cAMP-responsive genes, such as Tg, TPO, TSHR (Nguyen et al. 2000), and NIS (Chun et al. 2004). Our study has indicated the requirement of the CRE-like element in the human NUE for the cAMP-induced NUE activity, and the binding of CREB1, ATF1, and/or CREM to the CRE-like element (Taki et al. 2002).

Thyroid-specific genes Tg (Civitareale et al. 1989, Sinclair et al. 1990, Donda et al. 1991, Zannini et al. 1992, Berg et al. 1996, Espinoza et al. 2001) and TPO (Mizuno et al. 1991, Francis-Lang et al. 1992, Zannini et al. 1992, Miccadei et al. 2002) require both Pax-8 and TTF-1 for full gene expression. Recent studies have demonstrated the critical role of Pax- 8 in TSH regulation of NIS through the NUE (Ohno et al. 1999, Taki et al. 2002). The role of TTF-1, however, in human NIS gene expression, is likely less important. Overexpression of exogenous TTF-1 significantly increases the expression of $\mathrm{Tg}$ and TPO, but not NIS, in human thyroid cancer cells (Furuya et al. 2004b). TTF-1 is not recruited to the human NIS proximal promoter (Kogai et al. 2001) and does not stimulate promoter activity (Schmitt et al. 2001).

\section{Post-translational regulation of NIS by TSH}

TSH stimulates NIS expression at the post-translational level in FRTL-5 rat thyroid cells (Riedel et al. 2001). TSH stimulates NIS trafficking to the membrane and prolongs the half-life of NIS protein from 3 to 5 days (Riedel et al. 2001). Although TSH in the medium is required to maintain FRTL-5 cells (Ambesi-Impiombato et al. 1980), they can survive without TSH for up to 10 days (Kogai et al. 1997). The removal of TSH markedly reduces iodide uptake, NIS mRNA, and NIS protein expression in these cells (Kogai et al. 1997, Paire et al. 1997, Riedel et al. 2001). The addition of TSH restores NIS expression with a time lag between the induction of iodide uptake and NIS protein expression (Kogai et al. 1997). TSH induces NIS protein in $36 \mathrm{~h}$ to $\sim 80 \%$ maximum, while the iodide uptake reaches only $\sim 25 \%$ maximum at $36 \mathrm{~h}$ (Kogai et al. 1997). Immunocytochemistry in FRTL-5 cells shows an intense staining of NIS on plasma membrane with continuous TSH treatment, while intracellular staining is observed 3 days after withdrawal of TSH (Riedel et al. 2001).

The NIS protein in FRTL-5 cells is randomly distributed on the plasma membrane and does not exhibit cell polarity (Paire et al. 1997). In contrast, in normal thyroid gland, NIS protein is expressed on the basolateral membrane, but not on the apical side facing the lumen (Paire et al. 1997, Caillou et al. 1998, Jhiang et al. 1998, Castro et al. 1999). We developed a culture system for primary human thyroid cells, which survives for up to 3 months (Curcio et al. 1994, Kogai et al. 2000a). The primary cells in monolayer constitutively expressed the thyroid-specific genes, TTF-1, Pax-8, Tg, TPO, and NIS (Curcio et al. 1994, Perrella et al. 1997). TSH treatment stimulates cAMP production (Curcio et al. 1994) as well as the expression of NIS mRNA and protein (Kogai et al. 2000a). No significant induction of iodide uptake, however, was observed in the monolayer cells, even after TSH stimulation (Kogai et al. 2000a). Specific culture conditions promote the formation of threedimensional 'follicle-like' structures with a periodic acid schiff (PAS)-positive colloid filled lumen. In contrast to monolayers, TSH stimulation of the 
follicles results in significant induction of iodide uptake (Kogai et al. 2000a). These results indicate that cell polarity is required for the expression of the functional NIS in the human primary thyroid cells, which likely promotes NIS translocation to the basolateral membrane. The importance of thyroid follicle structure for NIS induction has been replicated in primary porcine thyroid preparations (Bernier-Valentin et al. 2006).

A role for NIS glycosylation and phosphorylation in the regulation of NIS trafficking to the membrane has been proposed (Dohan et al. 2003). The cytoplasmic carboxyl-terminal domain of NIS contains a PDZ target motif and a dileucine motif tail that are important for protein-protein interactions. A recent study reported that the deletion of these motifs prevented the transport and insertion of NIS protein into the plasma membrane (Dohan et al. 2005). Those motifs are likely to be involved in the post-translational regulation of NIS by TSH.

\section{NIS expression in thyroid cancer}

The NIS expression in the primary tumor of differentiated thyroid cancer has been studied extensively, although findings have differed. Several investigators reported reduced expressions of NIS mRNA and protein in papillary and follicular thyroid cancer (Smanik et al. 1997, Arturi et al. 1998, Caillou et al. 1998, Ryu et al. 1998, Lazar et al. 1999, Ringel et al. 2001). Increased NIS expression, however, has been reported in papillary cancer (Saito et al. 1998, Dohan et al. 2001, Wapnir et al. 2003). An immunohistochemical analysis of NIS with an affinity-purified high-sensitivity anti-human NIS polyclonal antibody has shown strong positive staining in $\sim 68 \%$ of the 72 cases of papillary cancer using conventional whole tissue sections (Wapnir et al. 2003).

NIS expression in the primary tumor of differentiated thyroid cancer and iodide uptake in recurrent or metastatic cancer, are correlated (Castro et al. 2001, Min et al. 2001). Positive NIS protein staining in primary intrathyroidal tumor was reported in $86 \%$ case of papillary cancer (Castro et al. 2001). The subsequent whole body scan with ${ }^{131} \mathrm{I}$, following the endogenous TSH stimulation achieved by thyroxine withdrawal, shows positive iodide uptake in metastatic tumor in 90\% patients with NIS-positive primary tumors (Castro et al. 2001). The expression of TSHR is usually retained in differentiated thyroid cancers (Brabant et al. 1991), except for insular carcinoma (Gerard et al. 2003), although significant cytoplasmic distribution has been observed (Mizukami et al. 1994, Gerard et al. 2003). A study with primary culture of papillary thyroid cancer cells has shown increased iodide uptake after TSH treatment (Saito et al. 1998), consistent with the data from clinical specimens.

In normal thyroid tissue, NIS protein is expressed on the basolateral membrane, even when the serum TSH level is in the normal range, while the NIS protein in differentiated thyroid cancer is expressed predominantly in the cytosol (Saito et al. 1998, Dohan et al. 2001, Wapnir et al. 2003). The loss of tissue polarity is a characteristic change seen in epithelial tumors (Fish \& Molitoris 1994). NIS-trafficking and correct polarity, therefore, are likely impaired in thyroid cancer. Our study with the three-dimensional culture of primary thyroid cells indicates the importance of cell polarity in the full expression of functional NIS (Kogai et al. 2000a). Restoration and/or stimulation of the trafficking of NIS in thyroid cancer are likely to increase the efficacy of ${ }^{131}$ I therapy.

\section{Transcriptional regulation of NIS in thyroid cancer}

Some thyroid papillary cancer cells express reduced NIS mRNA, likely due to the reduced activity of the NIS promoter (Kogai et al. 2001, Puppin et al. 2004). The human NIS gene region -596 to -415 has reduced promoter expression in thyroid cancer cells compared with FRTL-5 cells (Kogai et al. 2001). Binding of unknown nuclear factor(s) to the region -596 to -415 is decreased or absent in the BHP 2-7 cells compared with FRTL-5 cells (Kogai et al. 2001).

An anti-oxidative stress nuclear factor, Ref-1, is related to the upregulation of Pax- 8 by TSH in thyroid cells, stimulating the human NIS regulatory sequence (up to $-2.4 \mathrm{~kb}$ of $5^{\prime}$-flanking region) activity with Pax- 8 or an ubiquitous transcription factor early growth response (Egr)-1 in HeLa cells (Puppin et al. 2004). Impaired translocation of Ref-1 to the nuclei has been reported in papillary and anaplastic thyroid cancer cell lines as well as thyroid cancer tissues (Russo et al. 2001). The reduced NIS promoter activity in some thyroid cancer cells, therefore, may be due to the reduced Ref-1 localization in the nuclei (Puppin et al. 2004).

The potent enhancer NUE requires Pax- 8 binding for the full activity (Ohno et al. 1999, Taki et al. 2002). Endogenous Pax-8 expression is markedly reduced in $70 \%$ differentiated thyroid cancer, especially in aggressive disease (Fabbro et al. 1994, Puglisi et al. 2000).

Papillary thyroid cancer (20-85\% with geographic variation) has frequent somatic rearrangements of the RET receptor (RET/PTC; Santoro et al. 1992, 2002, Chua et al. 2000, Nikiforov 2002), leading to a constitutive activation of the RET tyrosine kinase. 
The auto-activated RET receptor stimulates cell proliferation and motility through the ERK-MAPK pathway (Melillo et al. 2005). One of the most common RET/PTC rearrangement, RET/PTC1, consists of the intracellular portion of RET with the tyrosine kinase domain fused to $\mathrm{H} 4$, a ubiquitous gene of unknown function. The RET/PCT1 expression impairs the activity of Pax-8, which is required for the full activation of the NUE (Ohno et al. 1999, Taki et al. 2002), in $\mathrm{PC} \mathrm{Cl} 3$ rat thyroid cells (De Vita et al. 1998). Reduced expression of NIS has been reported in a $\mathrm{PC} \mathrm{Cl} 3$ constitutively expressing exogenous RET/ PTC1 (Trapasso et al. 1999, Venkateswaran et al. 2004). In transgenic mice of thyroid cancer model with thyroid-targeted RET/PTC1 expression, iodide uptake is decreased in thyroid glands (Jhiang et al. 1996). In $\mathrm{RET} / \mathrm{PTC} 1$-expressing $\mathrm{PC} \mathrm{Cl} 3$ rat thyroid cells, there is reduced localization of PKA to the nucleus (Venkateswaran et al. 2004). Forskolin and substitution of exogenous PKA restore the NIS expression in the RET/ PTC1-expressing cells, suggesting interference of RET/PTC1 with PKA-dependent signaling. On the other hand, our study has indicated a partial interruption of the NUE by the blocking of MEK-ERK pathway in FRTL-5 rat thyroid cells (Taki et al. 2002). Activating mutations of BRAF (Kimura et al. 2003) and an activating rearrangement of the BRAF with A-kinase anchor protein 9 (AKAP9-BRAF; Ciampi et al. 2005) have been reported recently in some papillary thyroid cancer. Crosstalk between the ERK pathway and signaling to NIS gene expression remains to be further investigated.

\section{Promotion of NIS expression in thyroid cancer}

To achieve the maximum iodide uptake in metastaticdifferentiated thyroid cancer, TSH stimulation is required. This is achieved either by withdrawal of thyroid hormone replacement after a total thyroidectomy or by administration of rhTSH (Dow et al. 1997). The efficacy of rhTSH is generally equivalent to thyroid hormone withdrawal in the detection of thyroid cancer (Jarzab et al. 2003).

Some differentiated thyroid cancers (approximately 10-20\%), however, do not concentrate radioiodide, even after TSH stimulation (Robbins et al. 1991, Schmutzler \& Koehrle 2000). TSH unresponsiveness of NIS induction is unlikely to be due to the absence of TSHR. Almost all differentiated thyroid cancer expresses the TSHR protein (Brabant et al. 1991, Mizukami et al. 1994, Gerard et al. 2003). Reduced expression of TSHR, however, is associated with a poor prognosis in papillary thyroid cancer (Tanaka et al. 1997). Failure of signal transduction and/or transcription factors required for NIS gene expression is likely to be responsible for the lack of iodide accumulation in aggressive differentiated thyroid cancer. Defects in NIS protein trafficking and membrane insertion may also play a role. Recent studies have demonstrated the potential for NIS induction in aggressive thyroid cancer by re-differentiation agents, such as nuclear receptor ligands and inhibitors of epigenetic modifications.

\section{NIS induction by nuclear hormone receptor ligands}

Retinoic acid (RA), a vitamin A derivative, plays a pivotal role in development, differentiation, and cell growth. RA action is mediated through two families of nuclear receptors, retinoic acid receptors (RARs), and retinoid $\mathrm{X}$ receptors (RXRs). RA induces re-differentiation and apoptosis in cancer cells (Hong \& Itri 1994). In thyroid cancer cells, RA induces typeI 5'-deiodinase (Schreck et al. 1994) and NIS (Schmutzler et al. 1997). Treatment for $24 \mathrm{~h}$ with all-trans RA ( $\left.t \mathrm{RA} ; 10^{-6} \mathrm{M}\right)$ markedly increased NIS mRNA expression in two follicular thyroid cancer cell lines, FTC-133 and FTC-238 (Schmutzler et al. 1997). Treatment of FRTL-5 rat thyroid cells with $t$ RA, however, downregulates NIS mRNA (Schmutzler et al. 1997). These findings suggest differential regulation of NIS expression by RA in normal and malignant thyroid tissues.

Based on the findings of the RA induction of 'redifferentiation' in thyroid cancer cell lines, clinical trials have been conducted to evaluate the efficacy of RA for improving radioiodide uptake in recurrent/metastatic thyroid cancer (Simon et al. 1996, 1998, 2002a, Grunwald et al. 1998, Koerber et al. 1999, Gruning et al. 2003). In most of these studies, treatment with 13-cis RA has been used. 13-cis RA is isomerized to $t$ RA and/or 9-cis RA in tissues, and activates RAR and/ or RXR (Blaner 2001), with less toxicity (Hixson et al. 1979) and a longer half-life (Brazzell et al. 1983), compared with $t$ RA. These clinical studies have shown that $20-42 \%$ aggressive differentiated thyroid cancer responds to RA treatment by an increase in radioiodide uptake (Simon et al. 1996, 1998, 2002a, Grunwald et al. 1998, Koerber et al. 1999, Gruning et al. 2003, Coelho et al. 2004). In a study of 50 patients with advanced invasive or metastatic thyroid cancer and negative iodide scans, an oral dose of 13-cis RA $(1.5 \mathrm{mg} / \mathrm{kg}$ ) was given for 5 weeks (Simon et al. 2002a). After 13-cis RA treatment, 13 patients had a marked increase in radioiodide uptake in the invasive or metastatic tumor, and eight patients had a modest 
increase in radioiodide uptake (Simon et al. 2002a). Reduced tumor volume was observed in seven of the 21 cases with functional NIS expression after the treatment with $80-270 \mathrm{mCi}{ }^{131} \mathrm{I}$ following the 13-cis RA treatment (Simon et al. 2002a). In some published reports with a small number (5-25) of cases, a marked increase in iodide uptake has been shown in follicular cancer, but not in papillary cancer (Grunwald et al. 1998, Gruning et al. 2003, Coelho et al. 2004). The studies, however, have not been randomized prospective studies of matched groups that would be necessary to confirm an effect of RA treatment.

The first demonstration of in vitro NIS induction was in follicular thyroid cancer cell lines (Schmutzler et al. 1997). Differential response of some thyroid cancer cell lines to RA has been described; cell lines expressing both RAR $\beta$ and RXR $\gamma$ demonstrate significant growth suppression with RA, whereas cell lines lacking these isoforms do not respond to RA (Haugen et al. 2004). Differential expression of RAR isoform may be important to predict the NIS induction in thyroid cancer with RA treatment, as well as histological difference. NIS expression and iodide uptake are increased in some breast cancer cells (Kogai et al. 2000b, 2004). The duration of the NIS expression with maximum function, however, is only a few days during the in vivo RA treatment (Kogai et al. 2004). In addition, a large systemic dose $(160 \mathrm{mg} / \mathrm{kg})$ is required to maximize the uptake in the mouse models (Kogai et al. 2004). Further evaluations are likely to be required in aggressive thyroid cancer to adjust the dose and duration of RA, as well as relationship among the histology, the tumor RAR isoform expression profile, and the response to RA.

Stimulation of another nuclear receptor, PPAR- $\gamma$, increases NIS expression in some thyroid cancer cell lines in vitro. Troglitazone, a PPAR- $\gamma$ ligand, has been reported to increase the NIS mRNA significantly in the FTC-133 follicular thyroid cancer cell line and the TPC-1 papillary thyroid cancer cell line, but not in a Hurthle-cell cancer cell line (Park et al. 2005). Since troglitazone inhibits cell proliferation and induces apoptosis in some papillary thyroid cancer cell lines in vitro and in vivo (Ohta et al. 2001), a combination of troglitazone and radioiodide therapy might provide a synergistic inhibitory effect on some thyroid cancers.

\section{Alteration of chromatin structure with histone deacetylase (HDAC) inhibitor}

Epigenetic modifications, such as histone deacetylation and DNA hypermethylation, are commonly detected in human cancer cells, relevant to de-differentiation and proliferation. Alteration of these epigenetic changes has been a target for re-differentiation in cancer cells.

Histone acetyltransferases and HDACs affect the acetylation status of histones, influencing gene expression (Marks et al. 2001). Inhibitors of HDACs induce growth arrest, differentiation, and/or apoptosis in many cancer cells (Marks et al. 2001). Some HDAC inhibitors, such as depsipeptide (FR901228) and valproic acid, have been reported to increase NIS expression in thyroid cancer cell lines (Kitazono et al. 2001, Zarnegar et al. 2002, Fortunati et al. 2004, Furuya et al. 2004b).

Depsipeptide significantly induces NIS mRNA and iodide uptake in follicular thyroid cancer cell lines (FTC-133 and FTC-236) and two anaplastic cancer cell lines (SW-1736 and KAT-4) at a low concentration $(1 \mathrm{ng} / \mathrm{ml})$ in vitro (Kitazono et al. 2001). Pharmacokinetics of the depsipeptide in patients have indicated that levels of more than $500 \mathrm{ng} / \mathrm{ml}$ are achieved without significant toxicity, promising to obtain the NIS-inducible concentration in patients (Kitazono et al. 2001). Another group has tried depsipeptide in a papillary thyroid cancer cells (BHP 18-21v) and an anaplastic cancer cell line (ARO), and found that $3-10 \mathrm{ng} / \mathrm{ml}$ of depsipeptide induces the NIS mRNA, protein, and iodide uptake, as well as Tg and TPO in association with iodide organification (Furuya et al. 2004b). The expression of TTF-1, but not Pax-8, is increased by depsipeptide in both cell lines (Furuya et al. 2004b). Since the overexpression of exogenous TTF-1 induces Tg and TPO (Furuya et al. 2004a), TTF-1 is likely to be responsible for the induction of iodide organification and decreased iodide efflux by the treatment of depsipeptide. The in vivo effect of depsipeptide on the iodide uptake has been confirmed in a BHP $18-21 \mathrm{v}$ xenograft model (Furuya et al. 2004b).

Another HDAC inhibitor, trichostatin A (TSA), also induces NIS mRNA in some papillary cancer cell lines (Zarnegar et al. 2002, Furuya et al. 2004b), a follicular cancer cell line (Zarnegar et al. 2002), an anaplastic cancer cell line (Furuya et al. 2004b), and a Hurthlecell cancer cell line (Zarnegar et al. 2002). The induction of iodide uptake, however, has not yet been confirmed in thyroid cancer cells treated by TSA (Kogai et al. 2001).

Recently, the anticonvulsant valproic acid, acting as a HDAC inhibitor (Marks et al. 2001), has been shown to induce NIS expression in a papillary cancer cell line, NPA, and the anaplastic cancer cell line, ARO (Fortunati et al. 2004), although the induction is relatively modest. HDAC inhibitors, especially 
depsipeptide, have a potential to increase radioiodide uptake in some aggressive thyroid cancer tumors.

\section{Effects of hypermethylation on NIS promoter activity}

Expression of some tissue-specific genes is regulated by cytidine methylation in a $\mathrm{CpG}$ dinucleotide sequence on regulatory sequences near the transcription start site (Antequera et al. 1990). The prevalence of abnormal methylation pattern of selected genes in thyroid tumors is high (Matsuo et al. 1993). The human NIS gene has three CpG-rich regions around the translation start site, the core promoter region (about $100 \mathrm{bp}$ from the transcription start site), the $5^{\prime}$ untranslated region, and the coding region of the first exon (Venkataraman et al. 1999). The demethylation agent, 5-azacytidine, restores NIS mRNA expression and iodide uptake in three papillary cancer cell lines, NPA, KAT-5, and KAT-10, but not in two follicular cancer cell lines, MRO and WRO (Venkataraman et al. 1999). A correlation has been observed between the successful restoration of NIS expression by 5 -azacytidine and demethylation of the $5^{\prime}$-untranslated region (Venkataraman et al. 1999). On the other hand, their evaluation of methylation status in thyroid cancer tumor specimen has revealed no significant correlation between the methylation status of these CpG-rich regions and NIS mRNA expression in thyroid cancer tumor samples (Venkataraman et al. 1999). The hypermethylation of the NIS $5^{\prime}$-untranslated region could be one of the factors contributing to reduced NIS expression in some thyroid cancers. The demethylation agent, 5-azacytidine, has the potential to restore radioiodide uptake in some thyroid cancer tumors.

\section{Thyroid cancer models}

Concentration of radioiodine in response to TSH stimulation is observed in $70 \%$ of metastatic thyroid cancers (Robbins et al. 1991). However, only a few normal thyroid cell lines (Weiss et al. 1984b, Berlingieri et al. 1993, Venkataraman et al. 1998) and thyroid cancer cell lines (Ohta et al. 1996, 1997, Kogai et al. 2001) express endogenous NIS in response to TSH stimulation. Most of these thyroid cell lines have de-differentiated and lost expression of TSH-R and TTF-1, which are expressed in most differentiated thyroid cancers. Several transgenic mouse models of thyroid cancers have been developed with thyroid-targeted expression of oncogenes, including SV40-large $\mathrm{T}$ antigen (Ledent et al. 1991), human papilloma virus (HPV)-E7 oncogene (Ledent et al. 1995, Coppee et al. 1996), RET/PTC1 (Jhiang et al. 1996, Santoro et al. 1996), RET/PTC3 (Powell et al. 1998), and TRK-T1 (Russell et al. 2000).
These transgenic mice may provide better models to evaluate the regulation of NIS in thyroid cancer.

\section{NIS expression in normal breast tissue}

Iodide accumulation in the lactating breast has been recognized for more than 50 years (Honour et al. 1952, Brown-Grant 1957, Grosvenor 1960, Eskin et al. 1974, Thorpe 1976, Strum 1978, Bakheet et al. 1998, Perros et al. 2003). Once the NIS gene was cloned and available for study, a correlation between NIS expression and iodide uptake in lactating mammary glands was demonstrated (Cho et al. 2000, Tazebay et al. 2000). NIS is expressed on the basolateral membrane of alveolar cells in mammary glands (Spitzweg et al. 1998) and is markedly induced during lactation (Cho et al. 2000, Tazebay et al. 2000). The alveolar cells concentrate iodide in milk, 6 to 15 -fold relative to the plasma iodide concentration (Thorpe 1976). Part of the trapped iodide $(\sim 20 \%)$ is organified by peroxidases in the alveolar cells and lumens adjacent to the alveolar cells (Strum 1978, Etling \& Gehin-Fouque 1984, Shah et al. 1986).

Radioiodide therapy and imaging for thyroid diseases are contraindicated in breast-feeding patients. After thyroid imaging with ${ }^{131} \mathrm{I}$ or ${ }^{123} \mathrm{I}$, cessation of breast feeding is recommended until breast milk radioactivity levels are at a safe level (Stabin \& Breitz 2000). Since the therapeutic administration of ${ }^{131} \mathrm{I}$ for thyroid cancer $(150 \mathrm{mCi})$ delivers approximately $2 \mathrm{~Gy}(200 \mathrm{rad})$ to the mammary glands, it is recommended that breast feeding should be discontinued (Stabin \& Breitz 2000).

No correlation between thyroid uptake and breast uptake has been reported, suggesting differential regulation of iodide uptake in the thyroid and mammary glands (Eskin et al. 1974). Recent reports have demonstrated that fetoplacental estrogen and two pituitary hormones, oxytocin and prolactin, play an important role in the induction of NIS in the lactating mammary glands (Cho et al. 2000, Tazebay et al. 2000). Estradiol produces a modest induction of NIS in mammary glands from ovariectomized mice (Tazebay et al. 2000). In contrast, estradiol decreases the NIS expression in FRTL-5 rat thyroid cells (Furlanetto et al. 1999). The treatment of mice with the combination of oxytocin, prolactin, and estradiol markedly induces the NIS in mammary glands, while each hormone alone is not sufficient for NIS induction (Tazebay et al. 2000). Basal levels of these three hormones are significantly increased in late pregnancy and the lactogenic hormones, prolactin and oxytocin, are still elevated during the first few months of the post-partum period. The surge of oxytocin during 
lactation is likely to be important for the maximum induction of NIS in mammary glands.

There is a particular concern regarding the impact of ${ }^{131}$ I treatment for thyroid cancer in the post-partum period. Bromocriptine, which inhibits the secretion of prolactin, partially inhibits the iodide uptake in the lactating mammary glands in rats (Cho et al. 2000). Breast uptake of ${ }^{131}$ I during the treatment of thyroid cancer in the post-partum period may increase the risk of breast cancer (Preston et al. 2002, Zheng et al. 2002). Cessation of breast feeding and the administration of bromocriptine have been reported to reduce ${ }^{131}$ I uptake in breast tissues (Hsiao et al. 2004).

NIS activity is the primary regulator of iodide accumulation in the lactating breast, although other transporters may make a small contribution (Shennan 2001). A sulfate/iodide exchanger that is inhibited by 4,4'-diisothiocyanatostilbene $2,2^{\prime}$-disulfonic acid has been identified in rat mammary gland explants (Shennan 2001). Increased pendrin expression has also been reported in the lactating mammary gland (Rillema \& Hill 2003). Since NIS is expressed on the basolateral membrane in the lactating mammary glands, other transporters, like pendrin, may mediate release of the trapped iodide into the lumen.

\section{NIS expression and iodide uptake in breast cancer}

It has been recognized for over 30 years from case reports and small clinical series that radioiodide and ${ }^{99} \mathrm{TcO}_{4}^{-}$are concentrated in some breast cancer, but not in normal non-lactating breast tissue (Cancroft \& Goldsmith 1973, Eskin et al. 1974, Lyttle et al. 1979). Robust iodide uptake in estrogen-dependent breast cancer has been observed in rodent breast cancer models, with a magnitude of 5-7-fold, compared with plasma iodide concentration (Thorpe 1976, Briand 1983). Recently, the existence of NIS mRNA (Kilbane et al. 2000, Moon et al. 2001, Upadhyay et al. 2003) and protein expression (Tazebay et al. 2000, Rudnicka et al. 2003, Upadhyay et al. 2003, Wapnir et al. 2003, 2004) has been confirmed in human breast cancer tissues.

Immunohistochemical analysis of NIS protein expression in 169 cases of breast cancer from pathological archives identified positive staining of NIS in $88 \%$ ductal carcinoma in situ (strongly positive in 53\%), and $76 \%$ invasive carcinoma (strongly positive in 40\%; Wapnir et al. 2003). The NIS protein is expressed predominantly in the intracellular space, while NIS is on the basolateral membrane in lactating mammary glands (Wapnir et al. 2003). NIS trafficking to the plasma membrane may be impaired in some breast cancer, as it is in some differentiated thyroid cancers.

The correlation of ${ }^{99 \mathrm{~m}} \mathrm{TcO}_{4}^{-}$uptake and NIS mRNA expression in 25 patients with primary breast tumors, however, showed that only 4 out of 25 tumors with NIS mRNA expression had functional uptake (Moon et al. 2001). A disparity in NIS mRNA expression and iodide uptake has also been reported in some studies of thyroid cancer. These observations in breast cancer suggest that, in addition to NIS mRNA expression, NIS protein synthesis, modification, and membrane targeting are likely to be important in conferring iodide uptake.

There is very limited data on NIS expression and iodide uptake in metastatic breast tumors. Evaluation of nine cases of metastatic breast cancer showed three of them positive for NIS protein, and two of the three NIS-positive tumors concentrated ${ }^{123}$ I (Wapnir et al. 2004). The incidence of NIS protein positive tumors in metastatic disease is likely to be smaller than that in primary tumors, as differentiated function is often reduced in metastatic tumors (Wapnir et al. 2003). In thyroid cancer, NIS protein expression in the primary tumor is correlated with iodide uptake in metastatic and recurrent tumor, but only after TSH stimulation. Hormonal stimulation of NIS expression in breast cancer metastases is also likely to be important to achieve sufficient uptake for therapy.

NIS expression has been demonstrated in several transgenic mouse models of breast cancer (Tazebay et al. 2000, Knostman et al. 2004). In a study of transgenic mouse models that develop breast cancer, NIS expression in the tumors, as assessed by immunohistochemical staining, was present in 8 of the 14 models studied (Knostman et al. 2004). Strong NIS staining was observed in four models: two that overexpress the oncogenes HER2/neu or polyoma middle $\mathrm{T}$ antigen (PyVT) in mammary glands, one that overexpresses cyclooxygenase- 2 in mammary glands, and one that overexpresses hCG in a variety of tissues leading to a high circulating level of hCG (Rulli et al. 2003). Functional uptake of ${ }^{99 \mathrm{~m}} \mathrm{TcO}_{4}^{-}$was reported in two transgenic models with overexpression of Ras or HER2/neu oncogenes, although the uptake was modest (about 1.6-fold compared with the background; Tazebay et al. 2000). HER2/neu amplification/overexpression was found in 20-30\% human breast cancer (Ross and Fletcher 1998) and was associated with a more aggressive clinical course and decreased survival time compared with tumors with normal levels of HER2/neu (Slamon et al. 1989). Based on the findings in mouse models, HER2/neu overexpression in human 
breast cancer may indicate greater likelihood of enhanced NIS expression and the potential for radioiodide therapy.

\section{lodide organification and iodide retention in thyroid and breast cancers}

Iodide taken into the thyroid gland is organified, a process that promotes iodide retention by binding to thyroglobulin (Tg). The perchlorate discharge test was previously used clinically to identify organification defects in children, characterized by excessive loss of tracer radioiodine from the thyroid gland after administration of perchlorate. In normal thyroid glands, binding of iodide to tyrosyl residues on $\mathrm{Tg}$ is catalyzed by TPO, and this procedure requires $\mathrm{H}_{2} \mathrm{O}_{2}$, produced by ThOX 1 and ThOX2. The TPO and ThOXs are on the apical membrane and mediate the organification of iodide released through AIT and/or pendrin with the Tg accumulated in the lumen.

The extent of iodide organification in thyroid cancer has been characterized in only a few studies. In some differentiated thyroid cancer, the expressions of TPO (Czarnocka et al. 2001, Gerard et al. 2003) and pendrin (Gerard et al. 2003) are reduced. An immunohistochemical analysis indicated that the expressions of TPO and pendrin are markedly decreased in papillary cancer; only $1.5 \%$ cells stained for TPO compared with $92 \%$ in normal tissue and $0 \%$ for pendrin compared with $55 \%$ in normal tissue (Gerard et al. 2003). The expression of TPO in a study of follicular cancer showed reduced expression to $26 \%$ cells, although pendrin is more widely expressed (64\%; Gerard et al. 2003). ThOXs are expressed in almost every cancer. The distribution of TPO and ThOXs in these differentiated cancers is predominantly cytoplasmic (Gerard et al. 2003), demonstrating that the polarity for the iodide metabolism has been lost in these cancer tissues. Indeed, marked reduction of the TPO activity has been observed in papillary cancer tissues (Takamatsu et al. 1992). Absence of organification in metastatic thyroid cancer has been reported, even in those that concentrate radioiodide (Valenta 1966). Iodide organification in thyroid cancer is unlikely to be as efficient as the process in the normal thyroid.

The role of iodide organification in the treatment of thyroid cancer has not been established. Radioiodide therapy of thyroid cancer is usually carried out with elevated serum TSH. TSH increases the expression of TPO and Tg (Gerard et al. 1989, Nagayama et al. 1989), and synergistic trans-activation by TTF-1 and Pax-8 is required for the maximum induction of these genes in normal thyroid cells (Miccadei et al. 2002). The expression of Pax-8, however, is markedly reduced in about $70 \%$ of thyroid cancers (Fabbro et al. 1994, Puglisi et al. 2000). The iodide organification activity, therefore, is likely to be reduced in the majority of differentiated cancer, even after TSH stimulation. On the other hand, iodide organification and the biological half-life of radioiodide residence in tumors are significantly increased by the overexpression of TTF-1 in aggressive differentiated thyroid cancer cells, which express endogenous Pax-8, in vitro and in vivo (Furuya et al. $2004 a$ ). Iodide organification may have an important role in radioiodide therapy for some thyroid cancers with endogenous TTF- 1 and Pax-8 expressions.

The importance of iodide organification has been studied in several tumor models. NIS has been used for gene therapy in various xenograft models of thyroidal and non-thyroidal cancer cell lines with subsequent ${ }^{131} \mathrm{I}$ treatment. The efficacy of radioiodide, however, has varied among tumor types. Some have achieved tumor shrinkage after the administration of ${ }^{131}$ I (Spitzweg et al. 2000, 2001, Cho et al. 2002, Dingli et al. 2003, Faivre et al. 2004), while some reported no shrinkage or insufficient uptake for a therapeutic absorbed dose (Shimura et al. 1997, Smit et al. 2002, Haberkorn et al. 2003, 2004). Long-term retention of ${ }^{131} \mathrm{I}$ in the tumor, however, is likely to be important for effective treatment and can be achieved even in non-thyroidal cancer tissues without iodide organification (Dingli et al. 2004, Faivre et al. 2004). In an in vitro study of cells constitutively expressing exogenous NIS, but with no iodide organification activity, there was a positive correlation between the number of cells expressing NIS and the duration of iodide retention (Dingli et al. 2004). The addition of perchlorate significantly increases iodide efflux rate from these cells (Dingli et al. 2004). Since perchlorate inhibits the iodide uptake via NIS, these results suggest that re-uptake of iodide contributes to the retention of radioiodide in the cells (Dingli et al. 2004). Studies of a chemically induced rat liver cancer model has indicated a rapid efflux of radioiodide after the administration of perchlorate in NIS-expressing tumor cells (Faivre et al. 2004). They observed a long half-life of ${ }^{131} \mathrm{I}$ in the tumors, attributable to re-uptake via the high hepatic blood flow (Faivre et al. 2004). These data suggest that long retention of radioiodide can be achieved, even without iodide organification, if sufficient NIS is expressed in the tumor, and the tumor is fed with sufficient blood flow. Since metastatic tumors generally have an abundant blood supply, such tumors with sufficient NIS expression could be good candidates for radioiodide therapy. 
In the mammary gland, iodination of tyrosyl residues on caseins and other milk proteins correlates with peroxidase activity (Strum 1978, Shah et al. 1986). Iodide organification may occur even in inactive breast tissues (Strum et al. 1983). In contrast, iodide organification activity has not been observed in breast cancer. In GRS/A (GR) mice, which spontaneously develop breast adenocarcinomas, iodide uptake, and peroxidase activity in estrogen-dependent tumor are ten times greater than those in estrogen-independent tumor (Lyttle et al. 1979). The trapped iodide, however, is not organified in the tumor and no correlation has been reported between iodide uptake and peroxidase activity (Lyttle et al. 1979). An in vitro study showed no iodide organification in MCF-7 human breast cancer cells (Kogai et al. 2000b). Promotion of NIS expression in breast cancer, therefore, is important for greater efficacy of radioiodide therapy due to prolonged retention in the tumor.

\section{Promotion of the NIS expression in breast cancer}

The MCF-7 cell line, derived from adenocarcinoma metastatic to a pleural effusion, is the most commonly used breast cancer cell line model with endogenous estrogen receptor (ER) expression. MCF-7 cells express endogenous NIS, have modest iodide uptake, and have been widely used to study the hormonal regulation of iodide uptake and the NIS expression (Kogai et al. 2000b, 2004, 2005, Tanosaki et al. 2003, Knostman et al. 2004, Arturi et al. 2005). As shown in Table 2, several hormones and synthetic receptor ligands have been reported to increase iodide uptake and NIS mRNA expression in MCF-7 cells. Other cell lines and primary culture have also been utilized to demonstrate NIS induction (Cho et al. 2000, Tanosaki et al. 2003).

\section{Effects of lactogenic hormones on NIS expression in breast cancer cells}

NIS expression in lactating mammary glands is stimulated by prolactin, oxytocin, and estrogen (Tazebay et al. 2000). These hormones have been tested for their ability to induce NIS expression and iodide uptake in breast cancer cells (Cho et al. 2000, Kogai et al. 2000b, 2005, Arturi et al. 2005). Prolactin and oxytocin treatment markedly induced NIS mRNA in human breast cancer tissues cultured primarily on collagen gel, while the combination of these hormones did not produce an additive effect (Cho et al. 2000). The response to these hormones varied among the tumor specimens, but prolactin significantly induced NIS mRNA in all samples tested, and oxytocin in three of the four specimens. A significant induction in iodide
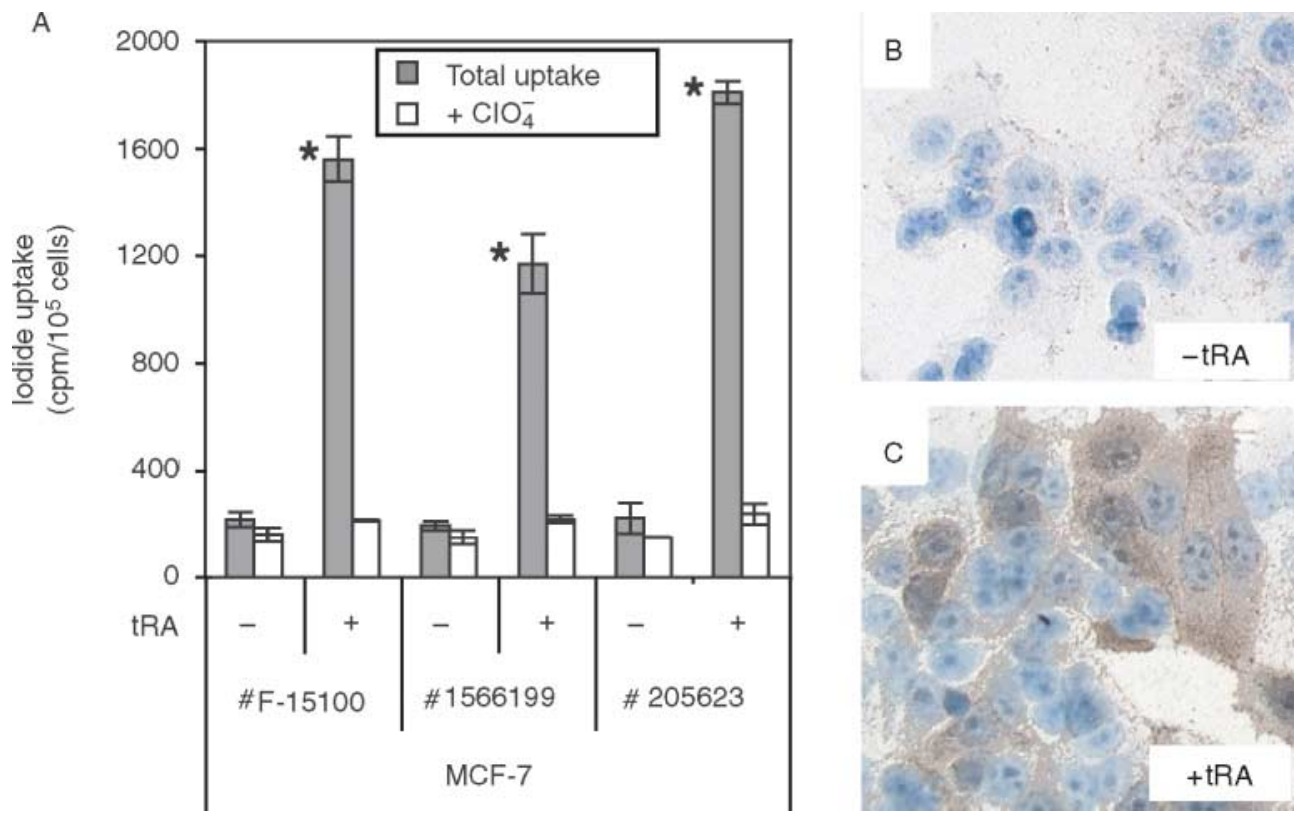

Figure 4 lodide uptake and NIS expression in all-trans RA (tRA)-stimulated MCF-7 cells. (A) lodide uptake in three lots of MCF-7 cells from ATCC (Manasas, VA, USA). The cells were treated with $10^{-6} \mathrm{M}$ tRA for $48 \mathrm{~h}$. ${ }^{*}, P<0.001$, comparison with the untreated group $(n=3)$. (B and C) Immunocytochemical staining with anti-human NIS antibody. Cells were treated with 0 (B) or $10^{-6} \mathrm{M}(\mathrm{C})$ of $t$ RA for $48 \mathrm{~h}$. These figures are reproduced from Kogai T, Kanamoto $\mathrm{Y}, \mathrm{Che} \mathrm{H}$, Taki K, Moatamed F, Schultz JJ \& Brent GA 2004 Systemic retinoic acid treatement induces sodium/iodide symporter expression and radioiodide uptake in mouse breast cancer models. Cancer Research 64 415-422. Reprinted with permission from the American Association for Cancer Research. 
uptake and NIS mRNA by prolactin was reported in the MCF-7 breast cancer cell line (Arturi et al. 2005). The duration of the prolactin induction, however, was relatively short with maximum iodide uptake at $12 \mathrm{~h}$, but reduced at $24 \mathrm{~h}$. This is in agreement with our study showing no significant induction of prolactin treatment on NIS expression in MCF-7 cells at $48 \mathrm{~h}$ (Kogai et al. $2000 b$ ). Estradiol does not significantly influence iodide uptake in the MCF-7 cells (Kogai et al. 2005), as is seen in normal breast tissue (Tazebay et al. 2000).

The mechanism of lactogenic hormone action on NIS gene expression has been partially characterized. Oxytocin receptor is a G-protein coupled receptor, and activates the cAMP/PKA pathway and/or the inositol triphosphate- $\mathrm{Ca}^{2+}$ pathway (Thibonnier et al. 1998). The contribution of cAMP and PI3K to NIS expression has been suggested by the findings in some transgenic mouse models of breast cancer (Knostman et al. 2004).
HER2/neu and PyVT, overexpressed in some models, have a tyrosine kinase domain and activate PI3K. Prostaglandins, whose production is stimulated by cyclooxygenase-2, and hCG increase cAMP accumulation by activation of prostaglandin and luteinizing hormone (LH) receptors respectively. Induction of NIS is seen with cAMP stimulation as well as a result of overexpression of PI3K in MCF-7 breast cancer cells in vitro (Knostman et al. 2004). The PI3K and cAMP pathways, therefore, are critical for NIS expression in these transgenic models (Knostman et al. 2004).

\section{Effects of retinoids on the NIS expression in breast cancer cells}

Retinoids have a robust effect inducing functional NIS in MCF-7 cells (Kogai et al. 2000b, 2005, Tanosaki et al. 2003). $t$ RA $\left(10^{-6} \mathrm{M}\right)$ markedly induces iodide uptake,

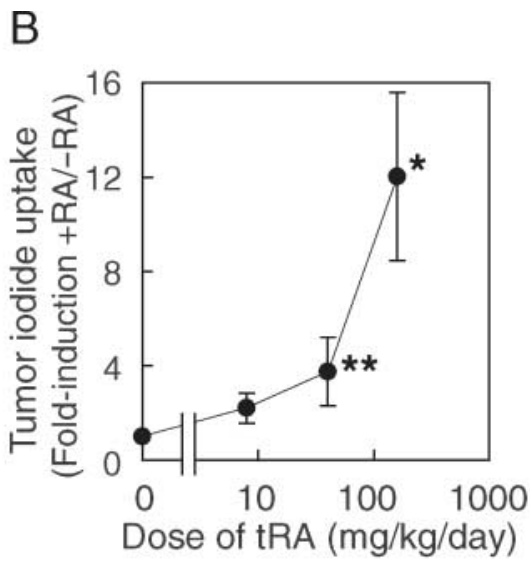

C
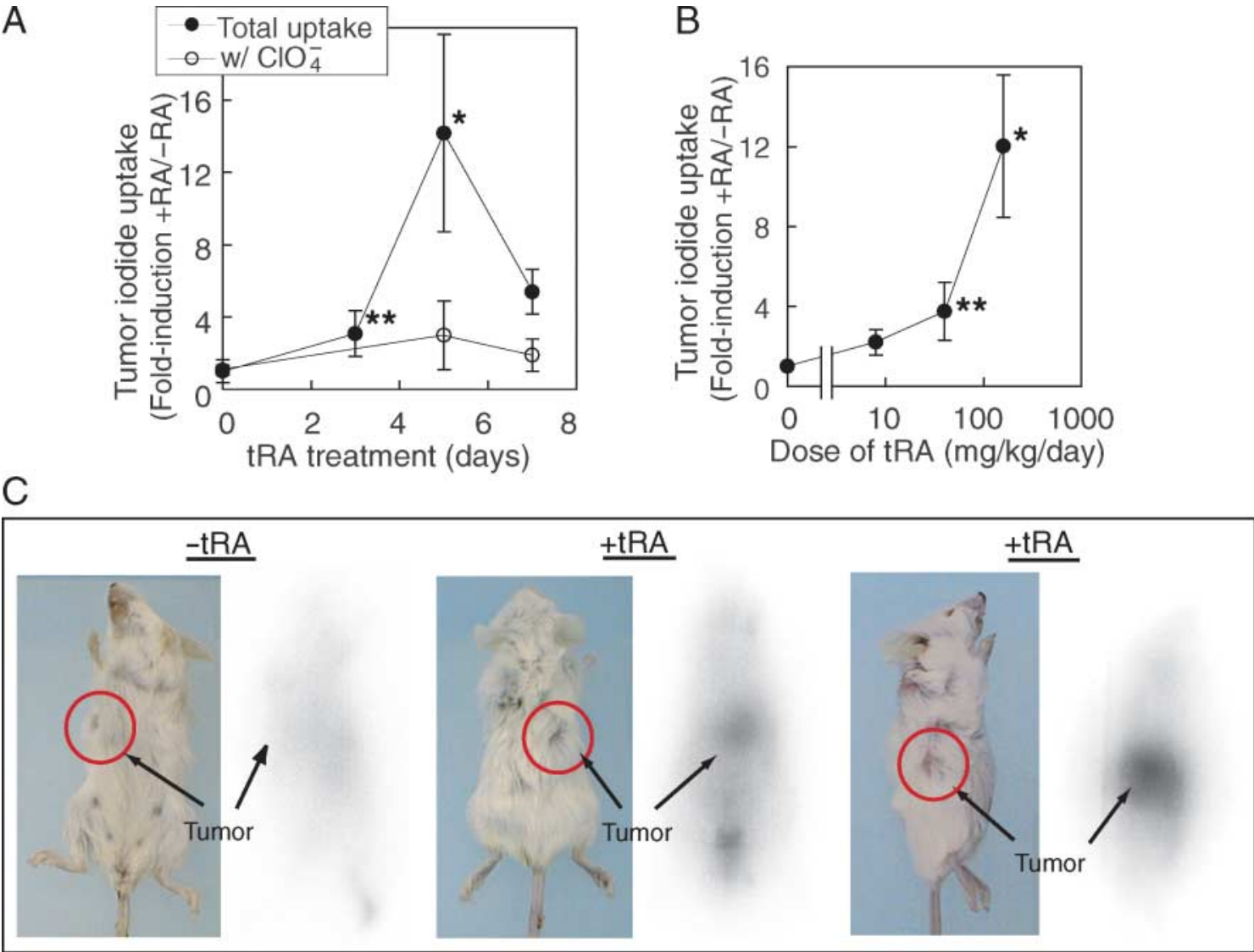

Figure 5 lodide uptake in MCF-7 xenograft tumor. (A) Time-course study with $160 \mathrm{mg} / \mathrm{kg}$ per day of systemic tRA treatment. (B) Effects of various dose of $t$ RA (5-days treatment) on the iodide uptake in vivo. ${ }^{*}, P=0.01 ; P=0.02$, comparisons with tumours from the untreated group $(n=3-6)$. (C) Imaging of the MCF-7 xenograft tumors with ${ }^{125}$. Systemic $t R A$ treatment (160 mg/kg per day for 5 days) visualizes the tumors $2 \mathrm{~h}$ after the administration of ${ }^{125} \mathrm{I}$. These figures are reproduced from Kogai $\mathrm{T}$, Kanamoto $\mathrm{Y}$, Che H, Taki K, Moatamed F, Schultz JJ \& Brent GA 2004 Systemic retinoic acid treatement induces sodium/iodide symporter expression and radioiodide uptake in mouse breast cancer models. Cancer Research 64 415-422. Reprinted with permission from the American Association for Cancer Research. 
up to 10-fold above the baseline, in three lots of MCF-7 cells (Fig. 4), although clonal variation in the hormone response of MCF-7 cells has been reported (Seibert et al. 1983). Our immunocytochemical analysis has demonstrated marked intracellular expression of NIS after $t$ RA treatment, and only faint staining of NIS in the absence of $t$ RA (Fig. 4). In contrast, ER-negative breast cancer cell line MDA-MB 231 shows no iodide uptake and NIS protein expression even after $t$ RA treatment.

Significant inductions of iodide uptake and NIS mRNA have been observed with isomers of $t \mathrm{RA}$, 9-cis RA, and 13-cis RA (Kogai et al. 2000b, 2005, Tanosaki et al. 2003). $t$ RA and 9-cis RA stimulate formation of heterodimers of the RAR and the RXR, and the RARRXR complex binds to its cis-element (retinoic acid response element, RARE) on a target gene to stimulate or suppress the transcription. $t \mathrm{RA}$ is a 'pan-retinoid' ligand to all RAR isomers, $\alpha, \beta$, and $\gamma$, but not RXRs (Allenby et al. 1993, Agarwal et al. 1996, Idres et al. 2002). 9-cis RA binds to a broader spectrum of retinoid receptors, RARs and RXRs, with almost equivalent affinity (Vuligonda et al. 2001, Idres et al. 2002). Although 13-cis RA has a low affinity for RARs and RXRs (Agarwal et al. 1996), it stimulates RARs, likely after isomerization to $t$ RA and 9-cis RA (Blaner 2001).

Differential regulation of gene expression by activation of each RAR isomer has been reported. To elucidate the isoform specificity of retinoid receptors for the upregulation of NIS gene expression, we have

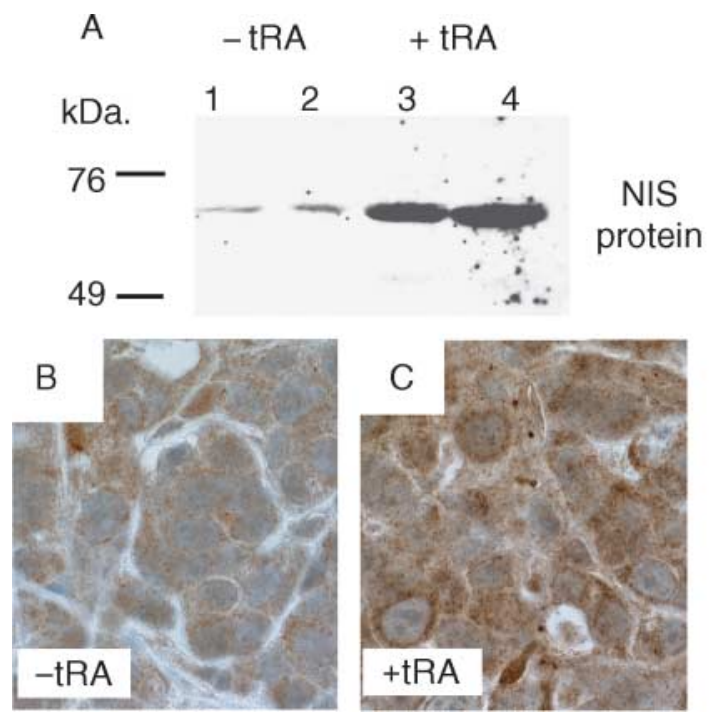

utilized isoform-selective retinoid receptor ligands in MCF-7 cells. An RAR $\beta / \gamma$ agonist (AGN190168) is a more potent inducer of functional NIS expression than AGN195183 (RAR $\alpha$ agonist), AGN194433 (RAR $\gamma$ agonist), and AGN194204 (pan-RXR ligand), suggesting a central role of RAR $\beta$ in NIS induction by retinoids (Kogai et al. 2005).

$t$ RA induces NIS gene expression partially at the transcriptional level (Kogai et al. 2000a). Our study with RAR-selective ligands has suggested that signaling through RAR $\beta$ is important for the RA induction of NIS mRNA (Kogai et al. 2005). The consensus sequence of RARE contains two of the core motifs, $5^{\prime}$-PuG[G/T][T/A]CA-3', directly repeating with a spacer of two or five bases (DR-2 or DR-5). Sequence inspection of the human NIS gene revealed two consensus DR-2 elements (AGGTCAggAGTTCA) in the first intron. These putative DR-2 elements, however, do not respond to $t \mathrm{RA}$ in MCF-7 cells ( $\mathrm{T}$ Kogai, Y Kanamoto \& G A Brent, unpublished observations). Interestingly, the DR-5, but not the DR2 , responds to the $t$ RA stimulation in MCF-7 cells (Kogai et al. 2003). Recently, the cardiac homeobox transcription factor, $\mathrm{Nkx}-2.5$, was shown to be induced by RA in MCF-7 cells, and involved in the RA induction of NIS, using the rat proximal promoter in MCF-7 cells (Dentice et al. 2004). These data suggest an indirect regulation of the NIS gene by RA through Nkx-2.5, but not through the RARE on the NIS gene.
$\mathrm{D}$

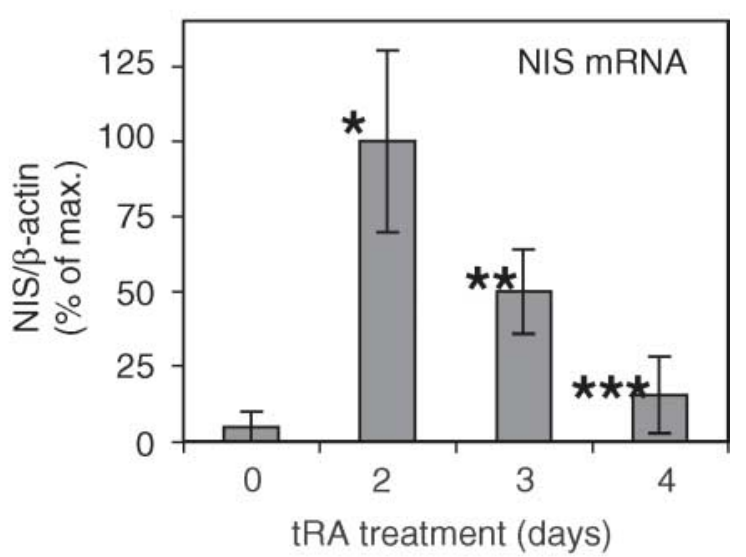

Figure 6 Induction of NIS protein (A, B, and C) and mRNA (D) expression by systemic tRA treatment in MCF-7 xenograft tumors. Western blot analysis (A) and immumohistochemical analysis (B and C) were performed after 5-days treatment with or without $160 \mathrm{mg} / \mathrm{kg}$ per day of $t$ RA. RT-PCR of NIS was performed after 2 days treatment with the same dose of $t$ RA. *,$P=0.005$ when compared with the untreated group. ${ }^{\star *}, P=0.02 ;{ }^{\star \star *}, P=0.008$, compared with the group at day $2(n=3)$. These figures are reproduced from Kogai T, Kanamoto Y, Che H, Taki K, Moatamed F, Schultz JJ \& Brent GA 2004 Systemic retinoic acid treatement induces sodium/iodide symporter expression and radioiodide uptake in mouse breast cancer models. Cancer Research 64 415-422. Reprinted with permission from the American Association for Cancer Research. 

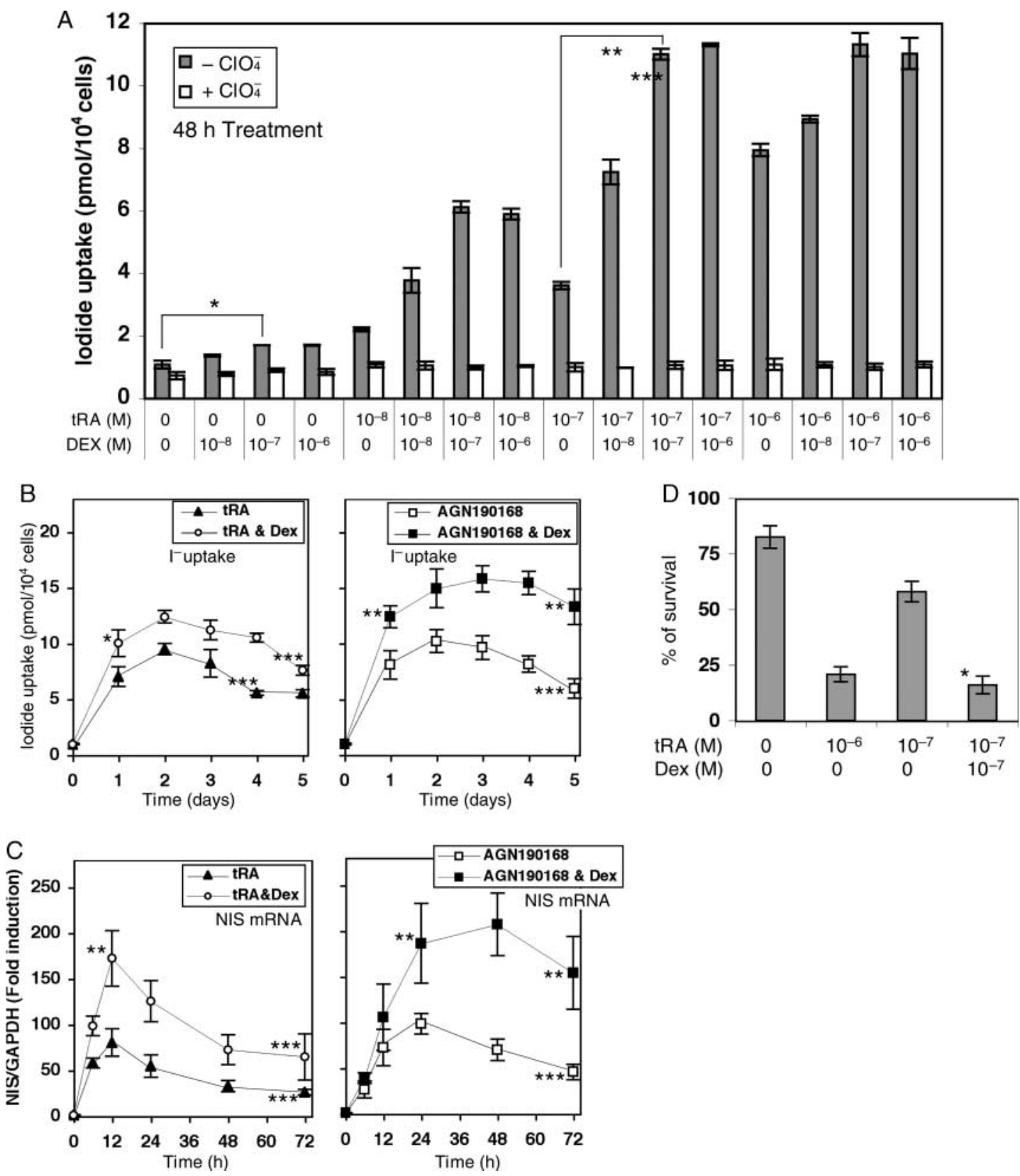

Figure 7 The effects of dexamethasone (Dex) on the retinoid-induced iodide uptake in MCF-7 cells in vitro. (A) Various dose combinations of Dex and $t R A$ were tested to induce iodide uptake in MCF-7 cells. Dex $\left(10^{-7} \mathrm{M}\right)$ enhances the uptake with $10^{-7} \mathrm{M} t R A$, resulting in more uptake than that with $10^{-6} \mathrm{M}$ tRA only. ${ }^{*}, P<0.02 ;{ }^{\star \star} P<0.001$ for comparison as shown $(n=3)$. ${ }^{\star \star \star}$, significant difference $(P<0.0001)$ in two-factor factorial ANOVA test among the four groups treated with 0 or $10^{-7} \mathrm{M} t \mathrm{RA}$ and/or $10^{-7} \mathrm{M}$ Dex. $(B$ and $C)$ Effects of long-term treatment with retinoids and Dex on iodide uptake (B) and NIS mRNA (C) in MCF-7 cells. Duration and magnitude of the NIS induction are markedly increased by the addition of Dex, especially in combination with an RAR $\beta / \gamma$ ligand AGN190168. * $P<0.05$; ${ }^{* *}, P<0.01$, compared with the group without Dex at the same time point $(n=3-4)$. ${ }^{\star \star \star}, P<0.05$ compared with the group of maximum value (at Day 2 of iodine uptake) and 12 or $24 \mathrm{~h}$ in NIS mRNA in the same treatment. (D) Selective cytotoxicity of ${ }^{131} \mathrm{I}$ in MCF-7 cells after the treatment with $t R A$ and Dex. MCF-7 cells were treated with the indicated concentration of $t R A$ and Dex for $48 \mathrm{~h}$, and then incubated with $60 \mu \mathrm{Ci} / \mathrm{ml}$ of ${ }^{131} \mathrm{I}$ for $6 \mathrm{~h}$. To estimate cell survival, clonogenic assay was carried out. The addition of Dex $\left(10^{-7} \mathrm{M}\right)$ significantly increases the cytotoxic effect of ${ }^{131}$ I after the treatment with $10^{-7} \mathrm{M} t \mathrm{RA}$. ${ }^{*}, P<0.001$, when compared with the group of unstimulated MCF-7 cells. These figures are reproduced from Kogai T, Kanamoto Y, Li Al, Che LH, Ohashi E, Taki K, Chandraratna RA, Saito T \& Brent GA 2005 Differential regulation of sodium/iodide symporter (NIS) gene expression by nuclear receptor ligands in MCF-7 breast cancer cells. Endocrinology 146 3059-3069. Reprinted with permission from The Endocrine Society. Copyright 2005 The Endocrine Society. 
Our in vivo studies with MCF-7 xenograft tumors in immunodeficient mice have demonstrated that induction of iodide uptake in the tumor by systemic $t$ RA treatment increases iodine concentration up to 15-fold above the background (Fig. 5A and B). This level is sufficient to visualize the tumors in imaging studies with ${ }^{125}$ I (Fig. 5C; Kogai et al. 2004). A modest amount of NIS protein expression is observed, predominantly in the intracellular space, and $t \mathrm{RA}$ increases NIS protein expression, but does not stimulate NIS trafficking to the membrane (Fig. 6). The effect of $t$ RA on the expression of functional NIS and its mRNA has been confirmed in another in vivo model, the transgenic mice overexpressing the PyVT oncogene in breast tissue (Kogai et al. 2004).

Greater and more sustained NIS induction is likely to be necessary for effective radioiodide therapy. Although the maximum induction of iodide uptake and expression are seen within 5 days, reduction in expression occurs within the next 2 days after the maximum induction (Fig. 5A and 6D). A large dose of RA ( $160 \mathrm{mg} / \mathrm{kg}$ per day) is required to induce NIS in these mouse models (Fig. 5B), although no significant toxicity was detected during the 5 days of treatment in mice (Kogai et al. 2004). The relative short duration of NIS induction and the potential for toxicity with high-dose RA need to be improved to achieve an adequate therapeutic response.

There are a number of approaches to block the uptake of high-dose radioiodide into the thyroid. Systemic thyroid hormone treatment has been successful in humans (Wapnir et al. 2004) and rodents (Spitzweg et al. 2001, Cho et al. 2002, Furuya et al. 2004a, Kogai et al. 2004). In our imaging study, the MCF-7 xenograft model mice were treated with thyroxine for 12 days and the thyroid gland was not visualized (Fig. 5C; Kogai et al. 2004). Since no significant NIS induction by $t$ RA has been observed in other organs expressing NIS, including thyroid, stomach, kidney, and normal mammary glands, the $t$ RA effect appears selective for the breast tumor (Kogai et al. 2004). Prior thyroid ablation by radioiodide or surgical removal followed by levothyroxine replacement could also be utilized.

\section{Effects of dexamethasone (Dex) on the RA-induced NIS expression}

Breast cancer has reduced iodide organification activity (Lyttle et al. 1979, Kogai et al. 2000b), greater and more sustained induction of NIS is important to achieve the prolonged iodide retention, as suggested by the kinetics study of iodide efflux (Dingli et al. 2004). Insulin, IGFs, and prolactin stimulate iodide uptake in MCF-7 breast cancer cells in vitro, but the duration is about $12 \mathrm{~h}$, followed by rapid reduction in the next $12 \mathrm{~h}$ (Arturi et al. 2005). Prostaglandin $E_{2}$ and hCG also induce NIS in the MCF-7 cells, likely via cAMP, but with relatively modest iodide uptake (2-3-fold induction; Knostman et al. 2004). Our in vivo study with MCF-7 xenografts has shown a marked induction of iodide uptake (about 15 -fold induction) with systemic retinoid treatment for 5 days, but followed by the rapid reduction in the next 2 days (Kogai et al. 2004).

We have recently found that Dex significantly increases the RA-induced iodide uptake (about 12-fold of that before the treatment) and NIS mRNA, partially by stabilizing the NIS mRNA, and prolongs the induction of iodide uptake (Kogai et al. 2005). The addition of Dex $\left(10^{-7} \mathrm{M}\right)$ reduces the median effective concentration $\left(\mathrm{EC}_{50}\right)$ of $t \mathrm{RA}$ for the induction of iodide uptake to $\sim 7 \%$ (Fig. 7A). The in vivo systemic dose of $t$ RA for the maximum induction of NIS is quite high (more than 100 times the clinical dose for acute promyclocytic leukemia). The combination treatment with Dex, therefore, has a potential to reduce the dose of RA, resulting an expected low toxicity in vivo. The reduced dose of $t$ RA $\left(10^{-7} \mathrm{M}\right)$ with Dex actually achieves cytotoxicity of ${ }^{131} \mathrm{I}$ in vitro clonogenic assay as well as $10^{-6} \mathrm{M} t \mathrm{RA}$ (Fig. 7B). Interestingly, duration of the iodide uptake and NIS mRNA with the AGN190168 (RAR $\beta / \gamma)$ is significantly longer than that with $t$ RA, especially in combination with Dex (Fig. 7C and D). Isoform-selective retinoid agonists may have a more specific action, and reduced risk of adverse effects, especially if lower doses could be used (Chandraratna 1998). The combination of an RAR isoform-selective ligand and Dex has a potential to provide a more effective induction of radioiodide uptake in some breast cancer likely with less toxicity.

\section{Conclusions}

The mechanism of TSH stimulation of NIS gene expression in the thyroid has been extensively studied and many of the factors involved in the signal transduction pathways have been identified. The regulation of NIS expression in thyroid cancer, however, has been much more difficult to characterize. Differential expression of several nuclear factors involved in NIS gene expression has been reported, comparing normal thyroid cells and aggressive thyroid cancer cells. These studies, however, have not consistently shown a requirement for a specific combination of transcription factors. Differentiation agents, such as RA, PPAR- $\gamma$ ligand, HDAC inhibitors, 
and de-methylation agents, have shown a modest effect inducing NIS expression in some thyroid cancer cell lines. None of these agents, however, has been shown to consistently enhance radioiodide uptake in human clinical studies. NIS protein is located on the basolateral membrane in normal thyroid and lactating mammary glands, while intracellular expression of NIS predominates in thyroid and breast cancer. TSH stimulates not only NIS gene expression, but also the translocation of NIS to the plasma membrane in the normal thyroid gland. Agents that promote posttranslational stimulation of NIS should be investigated to increase the efficacy of radioiodide therapy in thyroid and breast cancers. Three-dimensional primary culture of surgical specimens, followed by immunocytochemical analysis and iodide uptake assay, will be useful to evaluate the regulation of NIS translocation.

Recent studies promoting NIS expression in breast cancer models have demonstrated the potential utility of radioiodide therapy. Lactogenic hormones, cAMP stimulators, and retinoids, especially with glucocorticoid enhancement, have been shown to increase iodide uptake in breast cancer cells and in in vivo models. Further studies of the molecular mechanisms that underlie NIS stimulation by these hormones, as well as adjustment of dose and duration of these treatments to maximize the functional NIS expression, will be necessary to utilize radioiodide therapy in clinical breast cancer treatment.

\section{Acknowledgements}

We express our appreciation to Drs Jerome Hershman and Toshimasa Onaya for their seminal contributions to studies of NIS expression and their encouragement in our work. This review was supported by NIH RO1 CA089364 and VA merit review funds to GAB. The authors declare that there is no conflict of interest that would prejudice the impartiality of this scientific work.

\section{References}

Agarwal C, Chandraratna RA, Johnson AT, Rorke EA \& Eckert RL 1996 AGN193109 is a highly effective antagonist of retinoid action in human ectocervical epithelial cells. Journal of Biological Chemistry 271 12209-12212.

Ain KB, Tofiq S \& Taylor KD 1996 Antineoplastic activity of taxol against human anaplastic thyroid carcinoma cell lines in vitro and in vivo. Journal of Clinical Endocrinology and Metabolism 81 3650-3653.

Ajjan RA, Kamaruddin NA, Crisp M, Watson PF, Ludgate M \& Weetman AP 1998 Regulation and tissue distribution of the human sodium iodide symporter gene. Clinical Endocrinology 49 517-523.
Allenby G, Bocquel MT, Saunders M, Kazmer S, Speck J, Rosenberger M, Lovey A, Kastner P, Grippo JF, Chambon $\mathrm{P}$ et al. 1993 Retinoic acid receptors and retinoid $\mathrm{X}$ receptors: interactions with endogenous retinoic acids. PNAS 90 30-34.

Altschuler DL, Peterson SN, Ostrowski MC \& Lapetina EG 1995 Cyclic AMP-dependent activation of Rap1b. Journal of Biological Chemistry 270 10373-10376.

Ambesi-Impiombato FS, Parks LA \& Coon HG 1980 Culture of hormone-dependent functional epithelial cells from rat thyroids. PNAS 77 3455-3459.

Antequera F, Boyes J \& Bird A 1990 High levels of de novo methylation and altered chromatin structure at $\mathrm{CpG}$ islands in cell lines. Cell 62 503-514.

Armstrong R, Wen W, Meinkoth J, Taylor S \& Montminy M 1995 A refractory phase in cyclic AMP-responsive transcription requires down regulation of protein kinase A. Molecular and Cellular Biology 15 1826-1832.

Arturi F, Russo D, Schlumberger M, du Villard JA, Caillou B, Vigneri P, Wicker R, Chiefari E, Suarez HG \& Filetti S 1998 Iodide symporter gene expression in human thyroid tumors. Journal of Clinical Endocrinology and Metabolism $\mathbf{8 3}$ 2493-2496.

Arturi F, Presta I, Scarpelli D, Bidart JM, Schlumberger M, Filetti S \& Russo D 2002 Stimulation of iodide uptake by human chorionic gonadotropin in FRTL-5 cells: effects on sodium/iodide symporter gene and protein expression. European Journal of Endocrinology 147 655-661.

Arturi F, Ferretti E, Presta I, Mattei T, Scipioni A, Scarpelli D, Bruno R, Lacroix L, Tosi E, Gulino A et al. 2005

Regulation of iodide uptake and sodium/iodide symporter expression in the MCF-7 human breast cancer cell line. Journal of Clinical Endocrinology and Metabolism 90 2321-2326.

Asai T, Kambe F, Kikumori T \& Seo H 1997 Increase in Ref-1 mRNA and protein by thyrotropin in rat thyroid FRTL-5 cells. Biochemical and Biophysical Research Communications 236 71-74.

Bakheet SM, Powe J \& Hammami MM 1998 Unilateral radioiodine breast uptake. Clinical Nuclear Medicine 23 170-171.

Berg V, Vassart G \& Christophe D 1996 Identification of a thyroid-specific and cAMP-responsive enhancer in the upstream sequences of the human thyroglobulin promoter. Biochimica et Biophysica Acta 1307 35-38.

Berlingieri MT, Santoro M, Battaglia C, Grieco M \& Fusco A 1993 The Adenovirus E1A gene blocks the differentiation of a thyroid epithelial cell line, however the neoplastic phenotype is achieved only after cooperation with other oncogenes. Oncogene 8 249-255.

Bernier-Valentin F, Trouttet-Masson S, Rabilloud R, SelmiRuby S \& Rousset B 2006 Three-dimensional organization of thyroid cells into follicle structures is a pivotal factor in the control of sodium/iodide symporter expression. Endocrinology 147 2035-2042.

Bidart JM, Mian C, Lazar V, Russo D, Filetti S, Caillou B \& Schlumberger M 2000 Expression of pendrin and the 
pendred syndrome (PDS) gene in human thyroid tissues. Journal of Clinical Endocrinology and Metabolism 85 2028-2033.

Blaner WS 2001 Cellular metabolism and actions of 13-cisretinoic acid. Journal of the American Academy of Dermatology 45 S129-S135.

Boelaert K \& Franklyn JA 2003 Sodium iodide symporter: a novel strategy to target breast, prostate, and other cancers? Lancet 361 796-797.

Brabant G, Maenhaut C, Kohrle J, Scheumann G, Dralle H, Hoang-Vu C, Hesch RD, von zur Muhlen A, Vassart G \& Dumont JE 1991 Human thyrotropin receptor gene: expression in thyroid tumors and correlation to markers of thyroid differentiation and dedifferentiation. Molecular and Cellular Endocrinology 82 R7-R12.

Brazzell RK, Vane FM, Ehmann CW \& Colburn WA 1983 Pharmacokinetics of isotretinoin during repetitive dosing to patients. European Journal of Clinical Pharmacology 24 695-702.

Briand P 1983 Hormone-dependent mammary tumors in mice and rats as a model for human breast cancer (review). Anticancer Research 3 273-281.

Brown-Grant K 1957 The iodide concentrating mechanism of the mammary gland. Journal of Physiology 135 644-654.

Caillou B, Troalen F, Baudin E, Talbot M, Filetti S, Schlumberger M \& Bidart JM $1998 \mathrm{Na}+/ \mathrm{I}$ - symporter distribution in human thyroid tissues: an immunohistochemical study. Journal of Clinical Endocrinology and Metabolism 83 4102-4106.

Cancroft ET \& Goldsmith SJ 1973 99m Tc-pertechnetate scintigraphy as an aid in the diagnosis of breast masses. Radiology 106 441-444.

Carrasco N 1993 Iodide transport in the thyroid gland. Biochimica et Biophysica Acta 1154 65-82.

Cass LA \& Meinkoth JL 2000 Ras signaling through PI3K confers hormone-independent proliferation that is compatible with differentiation. Oncogene 19 924-932.

Castro MR, Bergert ER, Beito TG, McIver B, Goellner JR \& Morris JC 1999 Development of monoclonal antibodies against the human sodium iodide symporter: immunohistochemical characterization of this protein in thyroid cells. Journal of Clinical Endocrinology and Metabolism 84 2957-2962.

Castro MR, Bergert ER, Goellner JR, Hay ID \& Morris JC 2001 Immunohistochemical analysis of sodium iodide symporter expression in metastatic differentiated thyroid cancer: correlation with radioiodine uptake. Journal of Clinical Endocrinology and Metabolism 86 5627-5632.

Chandraratna RA 1998 Future trends: a new generation of retinoids. Journal of the American Academy of Dermatology 39 S149-S152.

Cho JY, Leveille R, Kao R, Rousset B, Parlow AF, Burak WE, Jr, Mazzaferri EL \& Jhiang SM 2000 Hormonal regulation of radioiodide uptake activity and $\mathrm{Na}+/ \mathrm{I}-$ symporter expression in mammary glands. Journal of Clinical Endocrinology and Metabolism 85 2936-2943.
Cho JY, Shen DH, Yang W, Williams B, Buckwalter TL, La Perle KM, Hinkle G, Pozderac R, Kloos R, Nagaraja HN et al. 2002 In vivo imaging and radioiodine therapy following sodium iodide symporter gene transfer in animal model of intracerebral gliomas. Gene Therapy 9 1139-1145.

Chua EL, Wu WM, Tran KT, McCarthy SW, Lauer CS, Dubourdieu D, Packham N, O'Brien CJ, Turtle JR \& Dong Q 2000 Prevalence and distribution of ret/ptc 1, 2, and 3 in papillary thyroid carcinoma in New Caledonia and Australia. Journal of Clinical Endocrinology and Metabolism 85 2733-2739.

Chun JT, Di Dato V, D’Andrea B, Zannini M \& Di Lauro R 2004 The CRE-like element inside the $5^{\prime}$-upstream region of the rat sodium/iodide symporter gene interacts with diverse classes of b-Zip molecules that regulate transcriptional activities through strong synergy with Pax-8. Molecular Endocrinology 18 2817-2829.

Ciampi R, Knauf JA, Kerler R, Gandhi M, Zhu Z, Nikiforova MN, Rabes HM, Fagin JA \& Nikiforov YE 2005 Oncogenic AKAP9-BRAF fusion is a novel mechanism of MAPK pathway activation in thyroid cancer. Journal of Clinical Investigation 115 94-101.

Civitareale D, Lonigro R, Sinclair AJ \& Di Lauro R 1989 A thyroid-specific nuclear protein essential for tissuespecific expression of the thyroglobulin promoter. The EMBO Journal 8 2537-2542.

Coelho SM, Corbo R, Buescu A, Carvalho DP \& Vaisman M 2004 Retinoic acid in patients with radioiodine nonresponsive thyroid carcinoma. Journal of Endocrinological Investigation 27 334-339.

Coppee F, Gerard AC, Denef JF, Ledent C, Vassart G, Dumont JE \& Parmentier M 1996 Early occurrence of metastatic differentiated thyroid carcinomas in transgenic mice expressing the $\mathrm{A} 2 \mathrm{a}$ adenosine receptor gene and the human papillomavirus type 16 E7 oncogene. Oncogene 13 1471-1482.

Coulonval K, Vandeput F, Stein RC, Kozma SC, Lamy F \& Dumont JE 2000 Phosphatidylinositol 3-kinase, protein kinase B and ribosomal S6 kinases in the stimulation of thyroid epithelial cell proliferation by cAMP and growth factors in the presence of insulin. Biochemical Journal 348 351-358.

Curcio F, Ambesi-Impiombato FS, Perrella G \& Coon HG 1994 Long-term culture and functional characterization of follicular cells from adult normal human thyroids. PNAS 91 9004-9008.

Czarnocka B, Pastuszko D, Janota-Bzowski M, Weetman AP, Watson PF, Kemp EH, McIntosh RS, Asghar MS, Jarzab B, Gubala E et al. 2001 Is there loss or qualitative changes in the expression of thyroid peroxidase protein in thyroid epithelial cancer? British Journal of Cancer $\mathbf{8 5}$ 875-880.

Dai G, Levy O \& Carrasco N 1996 Cloning and characterization of the thyroid iodide transporter. Nature 379 458-460. 
Daniels GH \& Haber DA 2000 Will radioiodine be useful in treatment of breast cancer? Nature Medicine 6 859-860.

De Deken X, Wang D, Many MC, Costagliola S, Libert F, Vassart G, Dumont JE, Libert F, Vassart G, Dumont JE \& Miot F 2000 Cloning of two human thyroid cDNAs encoding new members of the NADPH oxidase family. Journal of Biological Chemistry 275 23227-23233.

De Felice M \& Di Lauro R 2004 Thyroid development and its disorders: genetics and molecular mechanisms. Endocrine Reviews 25 722-746.

De Vita G, Zannini M, Cirafici AM, Melillo RM, Di Lauro R, Fusco A \& Santoro M 1998 Expression of the RET/PTC1 oncogene impairs the activity of TTF- 1 and Pax- 8 thyroid transcription factors. Cell Growth and Differentiation 9 97-103.

Dean DS \& Hay ID 2000 Prognostic indicators in differentiated thyroid carcinoma. Cancer Control 7 229-239.

Dentice M, Luongo C, Elefante A, Romino R, Ambrosio R, Vitale M, Rossi G, Fenzi G \& Salvatore D 2004 Transcription factor Nkx-2.5 induces sodium/iodide symporter gene expression and participates in retinoic acid- and lactation-induced transcription in mammary cells. Molecular and Cellular Biology 24 7863-7877.

Dingli D, Diaz RM, Bergert ER, O’Connor MK, Morris JC \& Russell SJ 2003 Genetically targeted radiotherapy for multiple myeloma. Blood 102 489-496.

Dingli D, Bergert ER, Bajzer Z, O'Connor MK, Russell SJ \& Morris JC 2004 Dynamic iodide trapping by tumor cells expressing the thyroidal sodium iodide symporter. Biochemical and Biophysical Research Communications 325 157-166.

Dohan O, Baloch Z, Banrevi Z, Livolsi V \& Carrasco N 2001 Rapid communication: predominant intracellular overexpression of the $\mathrm{Na}(+) / \mathrm{I}(-)$ symporter (NIS) in a large sampling of thyroid cancer cases. Journal of Clinical Endocrinology and Metabolism 86 2697-2700.

Dohan O, Ginter CS \& Carrasco N 2005 Role of the NIS $(\mathrm{Na}+/ \mathrm{I}-$ symporter) carboxy terminus in iodide transport. Thyroid 15 S-48.

Dohan O, De la Vieja A, Paroder V, Riedel C, Artani M, Reed M, Ginter CS \& Carrasco N 2003 The sodium/iodide symporter (NIS): characterization, regulation, and medical significance. Endocrine Reviews 24 48-77.

Donda A, Vassart G \& Christophe D 1991 Isolation and characterization of the canine thyroglobulin gene promoter region. Biochimica et Biophysica Acta 1090 235-237.

Dow KH, Ferrell BR \& Anello C 1997 Quality-of-life changes in patients with thyroid cancer after withdrawal of thyroid hormone therapy. Thyroid 7 613-619.

Dremier S, Vandeput F, Zwartkruis FJ, Bos JL, Dumont JE \& Maenhaut C 2000 Activation of the small G protein Rap1 in dog thyroid cells by both cAMP-dependent and independent pathways. Biochemical and Biophysical Research Communications 267 7-11.

Dunn JT \& Dunn AD 2001 Update on intrathyroidal iodine metabolism. Thyroid 11 407-414.
Eggo MC, Bachrach LK \& Mak W 1986 Disparate uptake of 99mTcO4- and 125I- in thyroid cells in culture. Hormone and Metabolic Research 18 167-172.

Endo T, Kaneshige M, Nakazato M, Ohmori M, Harii N \& Onaya T 1997 Thyroid transcription factor-1 activates the promoter activity of rat thyroid $\mathrm{Na}+/ \mathrm{I}-$ symporter gene. Molecular Endocrinology 11 1747-1755.

Eskin BA, Parker JA, Bassett JG \& George DL 1974 Human breast uptake of radioactive iodine. Obstetrics and Gynecology 44 398-402.

Espinoza CR, Schmitt TL \& Loos U 2001 Thyroid transcription factor 1 and Pax 8 synergistically activate the promoter of the human thyroglobulin gene. Journal of Molecular Endocrinology 27 59-67.

Etling N \& Gehin-Fouque F 1984 Iodinated compounds and thyroxine binding to albumin in human breast milk.

Pediatric Research 18 901-903.

Fabbro D, Di Loreto C, Beltrami CA, Di Lauro A \& Damante G 1994 Expression of thyroid-specific transcription factors TTF-1 and PAX-8 in human thyroid neoplasms. Cancer Research 54 4744-4749.

Faivre J, Clerc J, Gerolami R, Herve J, Longuet M, Liu B, Roux J, Moal F, Perricaudet M \& Brechot C 2004 Longterm radioiodine retention and regression of liver cancer after sodium iodide symporter gene transfer in Wistar rats. Cancer Research 64 8045-8051.

Fish EM \& Molitoris BA 1994 Alterations in epithelial polarity and the pathogenesis of disease states. New England Journal of Medicine 330 1580-1588.

Fortunati N, Catalano MG, Arena K, Brignardello E, Piovesan A \& Boccuzzi G 2004 Valproic acid induces the expression of the $\mathrm{Na}+/ \mathrm{I}-$ symporter and iodine uptake in poorly differentiated thyroid cancer cells. Journal of Clinical Endocrinology and Metabolism 89 1006-1009.

Francis-Lang H, Price M, Polycarpou-Schwarz M \& Di Lauro R 1992 Cell-type-specific expression of the rat thyroperoxidase promoter indicates common mechanisms for thyroid-specific gene expression. Molecular and Cellular Biology 12 576-588.

Furlanetto TW, Nguyen LQ \& Jameson JL 1999 Estradiol increases proliferation and down-regulates the sodium /iodide symporter gene in FRTL-5 cells. Endocrinology 140 5705-5711.

Furuya F, Shimura H, Miyazaki A, Taki K, Ohta K, Haraguchi K, Onaya T, Endo T \& Kobayashi T 2004a Adenovirus-mediated transfer of thyroid transcription factor-1 induces radioiodide organification and retention in thyroid cancer cells. Endocrinology 145 5397-5405.

Furuya F, Shimura H, Suzuki H, Taki K, Ohta K, Haraguchi K, Onaya T, Endo T \& Kobayashi T 2004b Histone deacetylase inhibitors restore radioiodide uptake and retention in poorly differentiated and anaplastic thyroid cancer cells by expression of the sodium/iodide symporter thyroperoxidase and thyroglobulin. Endocrinology 145 2865-2875. 
Garcia B \& Santisteban P 2002 PI3K is involved in the IGF-I inhibition of TSH-induced sodium/iodide symporter gene expression. Molecular Endocrinology 16 342-352.

Gerard AC, Daumerie C, Mestdagh C, Gohy S, De Burbure C, Costagliola S, Miot F, Nollevaux MC, Denef JF, Rahier J et al. 2003 Correlation between the loss of thyroglobulin iodination and the expression of thyroid-specific proteins involved in iodine metabolism in thyroid carcinomas. Journal of Clinical Endocrinology and Metabolism $\mathbf{8 8}$ 4977-4983.

Gerard CM, Lefort A, Christophe D, Libert F, Van Sande J, Dumont JE \& Vassart G 1989 Control of thyroperoxidase and thyroglobulin transcription by cAMP: evidence for distinct regulatory mechanisms. Molecular Endocrinology 3 2110-2118.

Gilliland FD, Hunt WC, Morris DM \& Key CR 1997 Prognostic factors for thyroid carcinoma. A populationbased study of 15698 cases from the surveillance, epidemiology and end results (SEER) program 19731991. Cancer 79 564-573.

Grosvenor CE 1960 Secretion of I131 into milk by lactating rat mammary glands. American Journal of Physiology 199 419-422.

Gruning T, Tiepolt C, Zophel K, Bredow J, Kropp J \& Franke WG 2003 Retinoic acid for redifferentiation of thyroid cancer-does it hold its promise? European Journal of Endocrinology 148 395-402.

Grunwald F, Menzel C, Bender H, Palmedo H, Otte R, Fimmers R, Risse J \& Biersack HJ 1998 Redifferentiation therapy-induced radioiodine uptake in thyroid cancer. Journal of Nuclear Medicine 39 1903-1906.

Haberkorn U, Kinscherf R, Kissel M, Kubler W, Mahmut M, Sieger S, Eisenhut M, Peschke P \& Altmann A 2003 Enhanced iodide transport after transfer of the human sodium iodide symporter gene is associated with lack of retention and low absorbed dose. Gene Therapy $\mathbf{1 0}$ 774-780.

Haberkorn U, Beuter P, Kubler W, Eskerski H, Eisenhut M, Kinscherf R, Zitzmann S, Strauss LG, DimitrakopoulouStrauss A \& Altmann A 2004 Iodide kinetics and dosimetry in vivo after transfer of the human sodium iodide symporter gene in rat thyroid carcinoma cells. Journal of Nuclear Medicine 45 827-833.

Harri N, Endo T, Ohmori M \& Onaya T 1999 Extracellular adenosine increases $\mathrm{Na}+/ 1-$ symporter gene expression in rat thyroid FRTL-5 cells. Molecular and Cellular Endocrinology 157 31-39.

Hata Y, Kaibuchi K, Kawamura S, Hiroyoshi M, Shirataki H \& Takai Y 1991 Enhancement of the actions of smg p21 GDP/GTP exchange protein by the protein kinase A-catalyzed phosphorylation of smg p21. Journal of Biological Chemistry 266 6571-6577.

Haugen BR, Larson LL, Pugazhenthi U, Hays WR, Klopper JP, Kramer CA \& Sharma V 2004 Retinoic acid and retinoid $\mathrm{X}$ receptors are differentially expressed in thyroid cancer and thyroid carcinoma cell lines and predict response to treatment with retinoids. Journal of Clinical Endocrinology and Metabolism 89 272-280.

Hershman JM 1999 Human chorionic gonadotropin and the thyroid: hyperemesis gravidarum and trophoblastic tumors. Thyroid 9 653-657.

Hershman JM, Blahd WH \& Gordon HE 1995 Thyroid gland. In Cancer Treatment, pp 743-752. Ed CM Haskell., 4th edn Philadelphia: WB Saunders.

Hixson EJ, Burdeshaw JA, Denine EP \& Harrison SD, Jr 1979 Comparative subchronic toxicity of all-trans- and 13-cis- retinoic acid in Sprague-Dawley rats. Toxicology and Applied Pharmacology 47 359-365.

Hong WK \& Itri LM 1994 Retinoids and human cancer. In The Retinoids: Biology, Chemistry, and Medicine, pp 597-630. Eds MB Sporn, AB Roberts \& DS Goodman. New York: Raven.

Honour AJ, Myant NB \& Rowlands EN 1952 Secretion of radioiodine in digestive juices and milk in man. Clinical Science 11 449-462.

Hsiao E, Huynh T, Mansberg R, Bautovich G \& Roach P 2004 Diagnostic I-123 scintigraphy to assess potential breast uptake of I-131 before radioiodine therapy in a postpartum woman with thyroid cancer. Clinical Nuclear Medicine 29 498-501.

Iacovelli L, Capobianco L, Salvatore L, Sallese M, D’Ancona GM \& De Blasi A 2001 Thyrotropin activates mitogenactivated protein kinase pathway in FRTL-5 by a cAMPdependent protein kinase A-independent mechanism. Molecular Pharmacology 60 924-933.

Idres N, Marill J, Flexor MA \& Chabot GG 2002 Activation of retinoic acid receptor-dependent transcription by alltrans-retinoic acid metabolites and isomers. Journal of Biological Chemistry 277 31491-31498.

Jarzab B, Handkiewicz-Junak D, Roskosz J, Puch Z, Wygoda Z, Kukulska A, Jurecka-Lubieniecka B, Hasse-Lazar K, Turska M \& Zajusz A 2003 Recombinant human TSHaided radioiodine treatment of advanced differentiated thyroid carcinoma: a single-centre study of 54 patients. European Journal of Nuclear Medicine and Molecular Imaging 30 1077-1086.

Jhiang SM, Sagartz JE, Tong Q, Parker-Thornburg J, Capen CC, Cho JY, Xing S \& Ledent C 1996 Targeted expression of the ret/PTC1 oncogene induces papillary thyroid carcinomas. Endocrinology 137 375-378.

Jhiang SM, Cho JY, Ryu KY, DeYoung BR, Smanik PA, McGaughy VR, Fischer AH \& Mazzaferri EL 1998 An immunohistochemical study of $\mathrm{Na}+/ \mathrm{I}-$ symporter in human thyroid tissues and salivary gland tissues. Endocrinology 139 4416-4419.

Kambe F, Nomura Y, Okamoto T \& Seo H 1996 Redox regulation of thyroid-transcription factors, Pax-8 and TTF-1, is involved in their increased DNA-binding activities by thyrotropin in rat thyroid FRTL-5 cells. Molecular Endocrinology 10 801-812. 
Kawasaki H, Springett GM, Mochizuki N, Toki S, Nakaya M, Matsuda M, Housman DE \& Graybiel AM 1998 A family of cAMP-binding proteins that directly activate Rap1. Science 282 2275-2279.

Kilbane MT, Ajjan RA, Weetman AP, Dwyer R, McDermott EW, O'Higgins NJ \& Smyth PP 2000 Tissue iodine content and serum-mediated 125I uptake-blocking activity in breast cancer. Journal of Clinical Endocrinology and Metabolism 85 1245-1250.

Kim JH \& Leeper RD 1983 Treatment of anaplastic giant and spindle cell carcinoma of the thyroid gland with combination Adriamycin and radiation therapy. A new approach. Cancer 52 954-957.

Kimura ET, Nikiforova MN, Zhu Z, Knauf JA, Nikiforov YE \& Fagin JA 2003 High prevalence of BRAF mutations in thyroid cancer: genetic evidence for constitutive activation of the RET/PTC-RAS-BRAF signaling pathway in papillary thyroid carcinoma. Cancer Research 63 1454-1457.

Kitazono M, Robey R, Zhan Z, Sarlis NJ, Skarulis MC, Aikou T, Bates S \& Fojo T 2001 Low concentrations of the histone deacetylase inhibitor, depsipeptide (FR901228), increase expression of the $\mathrm{Na}(+) / \mathrm{I}(-)$ symporter and iodine accumulation in poorly differentiated thyroid carcinoma cells. Journal of Clinical Endocrinology and Metabolism 86 3430-3435.

Knostman KA, Cho JY, Ryu KY, Lin X, McCubrey JA, Hla T, Liu CH, Di Carlo E, Keri R, Zhang M et al. 2004 Signaling through $3^{\prime}, 5^{\prime}$-cyclic adenosine monophosphate and phosphoinositide-3 kinase induces sodium/iodide symporter expression in breast cancer. Journal of Clinical Endocrinology and Metabolism 89 5196-5203.

Koerber C, Schmutzler C, Rendl J, Koehrle J, Griesser H, Simon D \& Reiners C 1999 Increased I-131 uptake in local recurrence and distant metastases after second treatment with retinoic acid. Clinical Nuclear Medicine 24 849-851.

Kogai T, Endo T, Saito T, Miyazaki A, Kawaguchi A \& Onaya T 1997 Regulation by thyroid-stimulating hormone of sodium/iodide symporter gene expression and protein levels in FRTL-5 cells. Endocrinology 138 2227-2232.

Kogai T, Curcio F, Hyman S, Cornford EM, Brent GA \& Hershman JM 2000a Induction of follicle formation in long-term cultured normal human thyroid cells treated with thyrotropin stimulates iodide uptake but not sodium/iodide symporter messenger RNA and protein expression. Journal of Endocrinology 167 125-135.

Kogai T, Schultz JJ, Johnson LS, Huang M \& Brent GA $2000 b$ Retinoic acid induces sodium/iodide symporter gene expression and radioiodide uptake in the MCF-7 breast cancer cell line. PNAS 97 8519-8524.

Kogai T, Hershman JM, Motomura K, Endo T, Onaya T \& Brent GA 2001 Differential regulation of the human sodium/iodide symporter gene promoter in papillary thyroid carcinoma cell lines and normal thyroid cells. Endocrinology 142 3369-3379.
Kogai T, Kanamoto Y \& Brent GA 2003 The modified firefly luciferase reporter gene (luc + ) but not Renilla luciferase is induced by all-trans retinoic acid in MCF-7 breast cancer cells. Breast Cancer Research and Treatment 78 119-126.

Kogai T, Kanamoto Y, Che LH, Taki K, Moatamed F, Schultz JJ \& Brent GA 2004 Systemic retinoic acid treatment induces sodium/iodide symporter expression and radioiodide uptake in mouse breast cancer models. Cancer Research 64 415-422.

Kogai T, Kanamoto Y, Li AI, Che LH, Ohashi E, Taki K, Chandraratna RA, Saito T \& Brent GA 2005 Differential regulation of sodium/iodide symporter (NIS) gene expression by nuclear receptor ligands in MCF-7 breast cancer cells. Endocrinology 146 3059-3069.

Lacroix L, Pourcher T, Magnon C, Bellon N, Talbot M, Intaraphairot T, Caillou B, Schlumberger M \& Bidart JM 2004 Expression of the apical iodide transporter in human thyroid tissues: a comparison study with other iodide transporters. Journal of Clinical Endocrinology and Metabolism 89 1423-1428.

Ladenson PW, Braverman LE, Mazzaferri EL, BruckerDavis F, Cooper DS, Garber JR, Wondisford FE, Davies TF, Degroot LJ, Daniels GH et al. 1997 Comparison of administration of recombinant human thyrotropin with withdrawal of thyroid hormone for radioactive iodine scanning in patients with thyroid carcinoma. New England Journal of Medicine 337 888-896.

Lazar V, Bidart JM, Caillou B, Mahe C, Lacroix L, Filetti S \& Schlumberger M 1999 Expression of the $\mathrm{Na}+/ \mathrm{I}-$ symporter gene in human thyroid tumors: a comparison study with other thyroid-specific genes. Journal of Clinical Endocrinology and Metabolism 84 3228-3234.

Ledent C, Dumont J, Vassart G \& Parmentier M 1991 Thyroid adenocarcinomas secondary to tissue-specific expression of simian virus-40 large T-antigen in transgenic mice. Endocrinology 129 1391-1401.

Ledent C, Marcotte A, Dumont JE, Vassart G \& Parmentier M 1995 Differentiated carcinomas develop as a consequence of the thyroid specific expression of a thyroglobulin-human papillomavirus type 16 E7 transgene. Oncogene 10 1789-1797.

Levy O, Dai G, Riedel C, Ginter CS, Paul EM, Lebowitz AN \& Carrasco N 1997 Characterization of the thyroid $\mathrm{Na}+/ \mathrm{I}-$ symporter with and anti-COOH terminus antibody. PNAS 94 5568-5573.

Lin X, Ryu KY \& Jhiang SM 2004 Cloning of the $5^{\prime}$-flanking region of mouse sodium/iodide symporter and identification of a thyroid-specific and TSH-responsive enhancer. Thyroid 14 19-27.

Lyttle CR, Thorpe SM, DeSombre ER \& Daehnfeldt JL 1979 Peroxidase activity and iodide uptake in hormoneresponsive and hormone-independent GR mouse mammary tumors. Journal of the National Cancer Institute 62 1031-1034.

Mandell RB, Mandell LZ \& Link CJ, Jr 1999 Radioisotope concentrator gene therapy using the sodium/iodide symporter gene. Cancer Research 59 661-668. 
Marks P, Rifkind RA, Richon VM, Breslow R, Miller T \& Kelly WK 2001 Histone deacetylases and cancer: causes and therapies. Nature Reviews Cancer 1 194-202.

Matsuo K, Tang SH, Zeki K, Gutman RA \& Fagin JA 1993 Aberrant deoxyribonucleic acid methylation in human thyroid tumors. Endocrinology 77 991-995.

Maxon HR, III \& Smith HS 1990 Radioiodine-131 in the diagnosis and treatment of metastatic well differentiated thyroid cancer. Endocrinology and Metabolism Clinics of North America 19 685-718.

Melillo RM, Castellone MD, Guarino V, De Falco V, Cirafici AM, Salvatore G, Caiazzo F, Basolo F, Giannini R, Kruhoffer M et al. 2005 The RET/PTC-RAS-BRAF linear signaling cascade mediates the motile and mitogenic phenotype of thyroid cancer cells. Journal of Clinical Investigation 115 1068-1081.

Mian C, Lacroix L, Alzieu L, Nocera M, Talbot M, Bidart JM, Schlumberger M \& Caillou B 2001 Sodium iodide symporter and pendrin expression in human thyroid tissues. Thyroid 11 825-830.

Miccadei S, De Leo R, Zammarchi E, Natali PG \& Civitareale D 2002 The synergistic activity of thyroid transcription factor 1 and Pax 8 relies on the promoter/enhancer interplay. Molecular Endocrinology 16 837-846.

Min JJ, Chung JK, Lee YJ, Jeong JM, Lee DS, Jang JJ, Lee MC \& Cho BY 2001 Relationship between expression of the sodium/iodide symporter and 131I uptake in recurrent lesions of differentiated thyroid carcinoma. European Journal of Nuclear Medicine 28 639-645.

Mizukami Y, Hashimoto T, Nonomura A, Michigishi T, Nakamura S, Noguchi M \& Matsukawa S 1994 Immunohistochemical demonstration of thyrotropin (TSH)receptor in normal and diseased human thyroid tissues using monoclonal antibody against recombinant human TSH-receptor protein. Journal of Clinical Endocrinology and Metabolism 79 616-619.

Mizuno K, Gonzalez FJ \& Kimura S 1991 Thyroid-specific enhancer-binding protein (T/EBP): cDNA cloning, functional characterization, and structural identity with thyroid transcription factor TTF-1. Molecular and Cellular Biology 11 4927-4933.

Moon DH, Lee SJ, Park KY, Park KK, Ahn SH, Pai MS, Chang H, Lee HK \& Ahn IM 2001 Correlation between 99mTc-pertechnetate uptakes and expressions of human sodium iodide symporter gene in breast tumor tissues. Nuclear Medicine and Biology 28 829-834.

Nagayama Y, Yamashita S, Hirayu H, Izumi M, Uga T, Ishikawa N, Ito K \& Nagataki S 1989 Regulation of thyroid peroxidase and thyroglobulin gene expression by thyrotropin in cultured human thyroid cells. Journal of Clinical Endocrinology and Metabolism 68 1155-1159.

Nakamura H, Nakamura K \& Yodoi J 1997 Redox regulation of cellular activation. Annual Review of Immunology 15 351-369.

Nguyen LQ, Kopp P, Martinson F, Stanfield K, Roth SI \& Jameson JL 2000 A dominant negative CREB (cAMP response element-binding protein) isoform inhibits thyrocyte growth, thyroid-specific gene expression, differentiation, and function. Molecular Endocrinology 14 1448-1461.

Niederle B, Roka R, Schemper M, Fritsch A, Weissel M, Weissel W \& Ramach W 1986 Surgical treatment of distant metastases in differentiated thyroid cancer: indication and results. Surgery 100 1088-1097.

Nikiforov YE 2002 RET/PTC rearrangement in thyroid tumors. Endocrine Pathology 13 3-16.

Ohmori M, Endo T, Harii N \& Onaya T 1998 A novel thyroid transcription factor is essential for thyrotropin-induced up-regulation of $\mathrm{Na}+/ \mathrm{I}-$ symporter gene expression. Molecular Endocrinology 12 727-736.

Ohno M, Zannini M, Levy O, Carrasco N \& di Lauro R 1999 The paired-domain transcription factor Pax 8 binds to the upstream enhancer of the rat sodium/iodide symporter gene and participates in both thyroid-specific and cyclicAMP-dependent transcription. Molecular and Cellular Biology 19 2051-2060.

Ohta K, Pang XP, Berg L \& Hershman JM 1996 Antitumor actions of cytokines on new human papillary thyroid carcinoma cell lines. Journal of Clinical Endocrinology and Metabolism 81 2607-2612.

Ohta K, Pang XP, Berg L \& Hershman JM 1997 Growth inhibition of new human thyroid carcinoma cell lines by activation of adenylate cyclase through the beta-adrenergic receptor. Journal of Clinical Endocrinology and Metabolism 82 2633-2638.

Ohta K, Endo T, Haraguchi K, Hershman JM \& Onaya T 2001 Ligands for peroxisome proliferator-activated receptor gamma inhibit growth and induce apoptosis of human papillary thyroid carcinoma cells. Journal of Clinical Endocrinology and Metabolism 86 2170-2177.

Paire A, Bernier-Valentin F, Selmi-Ruby S \& Rousset B 1997 Characterization of the rat thyroid iodide transporter using anti-peptide antibodies. Relationship between its expression and activity. Journal of Biological Chemistry 272 18245-18249.

Park JW, Zarnegar R, Kanauchi H, Wong MG, Hyun WC, Ginzinger DG, Lobo M, Cotter P, Duh QY \& Clark OH 2005 Troglitazone, the peroxisome proliferator-activated receptor-gamma agonist, induces antiproliferation and redifferentiation in human thyroid cancer cell lines. Thyroid 15 222-231.

Pekary AE \& Hershman JM 1998 Tumor necrosis factor, ceramide, transforming growth factor-beta1, and aging reduce $\mathrm{Na}+/ \mathrm{I}-$ symporter messenger ribonucleic acid levels in FRTL-5 cells. Endocrinology 139 703-712.

Perrella G, Fabbro D, Damante G, Di Loreto C, Beltrami CA, Curcio F \& Ambesi-Impiombato FS 1997 Expression of differentiation markers in cultured cells from various thyroid diseases. Thyroid 7 817-821.

Perros P, Mallick UK \& Fenwick JD 2003 Radioiodine uptake in normal female breasts and liver of a patient with differentiated thyroid cancer imaged by whole body scanning. Thyroid 13511. 
Pomerance M, Abdullah HB, Kamerji S, Correze C \& Blondeau JP 2000 Thyroid-stimulating hormone and cyclic AMP activate p38 mitogen-activated protein kinase cascade. Involvement of protein kinase A, rac1, and reactive oxygen species. Journal of Biological Chemistry 275 40539-40546.

Pomerance M, Carapau D, Chantoux F, Mockey M, Correze C, Francon J \& Blondeau JP 2003 CCAAT/enhancerbinding protein-homologous protein expression and transcriptional activity are regulated by $3^{\prime}, 5^{\prime}$-cyclic adenosine monophosphate in thyroid cells. Molecular Endocrinology 17 2283-2294.

Porra V, Ferraro-Peyret C, Durand C, Selmi-Ruby S, Giroud H, Berger-Dutrieux N, Decaussin M, Peix JL, Bournaud C, Orgiazzi J et al. 2005 Silencing of the tumor suppressor gene SLC5A8 is associated with BRAF mutations in classical papillary Thyroid carcinomas. Journal of Clinical Endocrinology and Metabolism 90 3028-3035.

Powell DJ, Jr, Russell J, Nibu K, Li G, Rhee E, Liao M, Goldstein M, Keane WM, Santoro M, Fusco A et al. 1998 The RET/PTC3 oncogene: metastatic solid-type papillary carcinomas in murine thyroids. Cancer Research $\mathbf{5 8}$ 5523-5528.

Preston DL, Mattsson A, Holmberg E, Shore R, Hildreth NG \& Boice JD, Jr 2002 Radiation effects on breast cancer risk: a pooled analysis of eight cohorts. Radiation Research 158 220-235.

Puglisi F, Cesselli D, Damante G, Pellizzari L, Beltrami CA \& Di Loreto C 2000 Expression of Pax-8, p53 and bcl-2 in human benign and malignant thyroid diseases. Anticancer Research 20 311-316.

Puppin C, Arturi F, Ferretti E, Russo D, Sacco R, Tell G, Damante G \& Filetti S 2004 Transcriptional regulation of human sodium/iodide symporter gene: a role for redox factor-1. Endocrinology 145 1290-1293.

Riedel C, Levy O \& Carrasco N 2001 Post-transcriptional regulation of the sodium/iodide symporter by thyrotropin. Journal of Biological Chemistry 276 21458-21463.

Riggs DS 1952 Quantitative aspects of iodine metabolism in man. Pharmacological Reviews 4 284-370.

Rillema JA \& Hill MA 2003 Prolactin regulation of the pendrin-iodide transporter in the mammary gland. American Journal of Physiology-Endocrinology and Metabolism 284 E25-E28.

Rillema JA, Yu TX \& Jhiang SM 2000 Effect of prolactin on sodium iodide symporter expression in mouse mammary gland explants. American Journal of Physiology, Endocrinology and Metabolism 279 769-772.

Ringel MD, Anderson J, Souza SL, Burch HB, Tambascia M, Shriver CD \& Tuttle RM 2001 Expression of the sodium iodide symporter and thyroglobulin genes are reduced in papillary thyroid cancer. Modern Pathology 14 289-296.

Robbins J, Merino MJ, Boice JD, Jr, Ron E, Ain KB, Alexander HR, Norton JA \& Reynolds J 1991 Thyroid cancer: a lethal endocrine neoplasm. Annals of Internal Medicine 115 133-147.
Rodriguez AM, Perron B, Lacroix L, Caillou B, Leblanc G, Schlumberger M, Bidart JM \& Pourcher T 2002 Identification and characterization of a putative human iodide transporter located at the apical membrane of thyrocytes. Journal of Clinical Endocrinology and Metabolism 87 3500-3503.

de Rooij J, Rehmann H, van Triest M, Cool RH, Wittinghofer A \& Bos JL 2000 Mechanism of regulation of the Epac family of cAMP-dependent RapGEFs. Journal of Biological Chemistry 275 20829-20836.

Ross JS \& Fletcher JA 1998 The HER-2/neu oncogene in breast cancer: prognostic factor, predictive factor, and target for therapy. Stem Cells 16 413-428.

Rothwell DG, Barzilay G, Gorman M, Morera S, Freemont P \& Hickson ID 1997 The structure and functions of the HAP1/Ref-1 protein. Oncology Research 9 275-280.

Royaux IE, Suzuki K, Mori A, Katoh R, Everett LA, Kohn LD \& Green ED 2000 Pendrin, the protein encoded by the Pendred syndrome gene (PDS), is an apical porter of iodide in the thyroid and is regulated by thyroglobulin in FRTL-5 cells. Endocrinology 141 839-845.

Rudnicka L, Sinczak A, Szybinski P, Huszno B \& Stachura J 2003 Expression of the $\mathrm{Na}(+) / \mathrm{I}(-)$ symporter in invasive ductal breast cancer. Folia Histochemistry and Cytobiology 41 37-40.

Rulli SB, Ahtiainen P, Makela S, Toppari J, Poutanen M \& Huhtaniemi I 2003 Elevated steroidogenesis, defective reproductive organs, and infertility in transgenic male mice overexpressing human chorionic gonadotropin. Endocrinology 144 4980-4990.

Russell JP, Powell DJ, Cunnane M, Greco A, Portella G, Santoro M, Greco A, Portella G, Santoro M, Fusco A \& Rothstein JL 2000 The TRK-T1 fusion protein induces neoplastic transformation of thyroid epithelium. Oncogene 19 5729-5735.

Russo D, Arturi F, Bulotta S, Pellizzari L, Filetti S, Manzini G, Damante G \& Tell G 2001 ApeI/Ref-I expression and cellular localization in human thyroid carcinoma cell lines. Journal of Endocrinological Investigation $\mathbf{2 4}$ RC10-RC12.

Ryu KY, Tong Q \& Jhiang SM 1998 Promoter characterization of the human $\mathrm{Na}+/ \mathrm{I}-$ symporter. Journal of Clinical Endocrinology and Metabolism 83 3247-3251.

Saito T, Endo T, Kawaguchi A, Ikeda M, Nakazato M, Kogai $\mathrm{T} \&$ Onaya $\mathrm{T} 1997$ Increased expression of the $\mathrm{Na}+/ \mathrm{I}-$ symporter in cultured human thyroid cells exposed to thyrotropin and in Graves' thyroid tissue. Journal of Clinical Endocrinology and Metabolism 82 3331-3336.

Saito T, Endo T, Kawaguchi A, Ikeda M, Katoh R, Kawaoi A, Muramatsu A \& Onaya T 1998 Increased expression of the sodium/iodide symporter in papillary thyroid carcinomas. Journal of Clinical Investigation 101 1296-1300.

Saito J, Kohn AD, Roth RA, Noguchi Y, Tatsumo I, Hirai A, Suzuki K, Kohn LD, Saji M \& Ringel MD 2001 Regulation of FRTL-5 thyroid cell growth by phosphatidylinositol $(\mathrm{OH}) 3$ kinase-dependent Akt-mediated signaling. Thyroid 11 339-351. 
Santoro M, Carlomagno F, Hay ID, Herrmann MA, Grieco M, Melillo R, Pierotti MA, Bongarzone I, Della Porta G, Berger $\mathrm{N}$ et al. 1992 Ret oncogene activation in human thyroid neoplasms is restricted to the papillary cancer subtype. Journal of Clinical Investigation 89 1517-1522.

Santoro M, Chiappetta G, Cerrato A, Salvatore D, Zhang L, Manzo G, Picone A, Portella G, Santelli G, Vecchio G et al. 1996 Development of thyroid papillary carcinomas secondary to tissue-specific expression of the RET/PTC1 oncogene in transgenic mice. Oncogene 12 1821-1826.

Santoro M, Papotti M, Chiappetta G, Garcia-Rostan G, Volante M, Johnson C, Camp RL, Pentimalli F, Monaco C, Herrero A et al. 2002 RET activation and clinicopathologic features in poorly differentiated thyroid tumors. Journal of Clinical Endocrinology and Metabolism 87 370-379.

Schlumberger MJ 1998 Papillary and follicular thyroid carcinoma. New England Journal of Medicine 338 297-306.

Schmitt TL, Espinoza CR \& Loos U 2001 Transcriptional regulation of the human sodium/iodide symporter gene by Pax8 and TTF-1. Experimental and Clinical Endocrinology and Diabetes 109 27-31.

Schmitt TL, Espinoza CR \& Loos U 2002 Characterization of a thyroid-specific and cyclic adenosine monophosphateresponsive enhancer far upstream from the human sodium iodide symporter gene. Thyroid 12 273-279.

Schmutzler C \& Koehrle J 2000 Innovative strategies for the treatment of thyroid cancer. European Journal of Endocrinology 143 15-24.

Schmutzler C, Winzer R, Meissner-Weigl J \& Kohrle J 1997 Retinoic acid increases sodium/iodide symporter mRNA levels in human thyroid cancer cell lines and suppresses expression of functional symporter in nontransformed FRTL-5 rat thyroid cells. Biochemical and Biophysical Research Communications 240 832-838.

Schreck R, Schnieders F, Schmutzler C \& Kohrle J 1994 Retinoids stimulate type I iodothyronine $5^{\prime}$-deiodinase activity in human follicular thyroid carcinoma cell lines. Journal of Clinical Endocrinology and Metabolism 79 791-798.

Seibert K, Shafie SM, Triche TJ, Whang-Peng JJ, O'Brien SJ, Toney JH, Huff KK \& Lippman ME 1983 Clonal variation of MCF-7 breast cancer cells in vitro and in athymic nude mice. Cancer Research 43 2223-2239.

Shah NM, Eskin BA, Krouse TB \& Sparks CE 1986 Iodoprotein formation by rat mammary glands during pregnancy and early postpartum period. Proceedings of Society for Experimental Biology and Medicine $\mathbf{1 8 1}$ 443-449.

Shennan DB 2001 Iodide transport in lactating rat mammary tissue via a pathway independent from the $\mathrm{Na}+/ \mathrm{I}-$ cotransporter: evidence for sulfate/iodide exchange. Biochemical and Biophysical Research Communications 280 1359-1363.

Shimaoka K, Schoenfeld DA, DeWys WD, Creech RH \& DeConti R 1985 A randomized trial of doxorubicin versus doxorubicin plus cisplatin in patients with advanced thyroid carcinoma. Cancer 56 2155-2160.
Shimura H, Haraguchi K, Miyazaki A, Endo T \& Onaya T 1997 Iodide uptake and experimental 131I therapy in transplanted undifferentiated thyroid cancer cells expressing the $\mathrm{Na}+/ \mathrm{I}-$ symporter gene. Endocrinology 138 4493-4496.

Simon D, Kohrle J, Schmutzler C, Mainz K, Reiners C \& Roher HD 1996 Redifferentiation therapy of differentiated thyroid carcinoma with retinoic acid: basics and first clinical results. Experimental and Clinical Endocrinology \& Diabetes 104 (Suppl 4) 13-15.

Simon D, Koehrle J, Reiners C, Boerner AR, Schmutzler C, Mainz K, Goretzki PE \& Roeher HD 1998 Redifferentiation therapy with retinoids: therapeutic option for advanced follicular and papillary thyroid carcinoma. World Journal of Surgery 22 569-574.

Simon D, Korber C, Krausch M, Segering J, Groth P, Gorges R, Grunwald F, Muller-Gartner HW, Schmutzler C, Kohrle J et al. 2002 a Clinical impact of retinoids in redifferentiation therapy of advanced thyroid cancer: final results of a pilot study. European Journal of Nuclear Medicine and Molecular Imaging 29 775-782.

Simon SL, Luckyanov N, Bouville A, VanMiddlesworth L \& Weinstock RM 2002b Transfer of 131I into human breast milk and transfer coefficients for radiological dose assessments. Health Physics 82 796-806.

Sinclair AJ, Lonigro R, Civitareale D, Ghibelli L \& Di Lauro R 1990 The tissue-specific expression of the thyroglobulin gene requires interaction between thyroid-specific and ubiquitous factors. European Journal of Biochemistry 193 311-318.

Slamon DJ, Godolphin W, Jones LA, Holt JA, Wong SG, Keith DE, Levin WJ, Stuart SG, Udove J, Ullrich A et al. 1989 Studies of the HER-2/neu proto-oncogene in human breast and ovarian cancer. Science 244 707-712.

Smanik PA, Ryu KY, Theil KS, Mazzaferri EL \& Jhiang SM 1997 Expression, exon-intron organization, and chromosome mapping of the human sodium iodide symporter. Endocrinology 138 3555-3558.

Smit JW, Schroder-van der Elst JP, Karperien M, Que I, Stokkel M, van der Heide D \& Romijn JA 2002 Iodide kinetics and experimental (131)I therapy in a xenotransplanted human sodium-iodide symporter-transfected human follicular thyroid carcinoma cell line. Journal of Clinical Endocrinology and Metabolism 87 1247-1253.

Spitzweg C \& Morris JC 2002 The sodium iodide symporter: its pathophysiological and therapeutic implications. Clinical Endocrinology (Oxford) 57 559-574.

Spitzweg C, Joba W \& Heufelder AE 1998 Analysis of human sodium iodide symporter gene expression in extrathyroidal tissues and cloning of its complementary deoxyribonucleic acids from salivary gland, mammary gland, and gastric mucosa. Journal of Clinical Endocrinology and Metabolism 83 1746-1751.

Spitzweg C, O'Connor MK, Bergert ER, Tindall DJ, Young CY \& Morris JC 2000 Treatment of prostate cancer by 
radioiodine therapy after tissue-specific expression of the sodium iodide symporter. Cancer Research $\mathbf{6 0}$ 6526-6530.

Spitzweg C, Dietz AB, O’Connor MK, Bergert ER, Tindall DJ, Young CY \& Morris JC 2001 In vivo sodium iodide symporter gene therapy of prostate cancer. Gene Therapy 8 1524-1531.

Stabin MG \& Breitz HB 2000 Breast milk excretion of radiopharmaceuticals: mechanisms, findings, and radiation dosimetry. Journal of Nuclear Medicine $\mathbf{4 1}$ 863-873.

Strum JM 1978 Site of iodination in rat mammary gland. Anatomical Record 192 235-244.

Strum JM, Phelps PC \& McAtee MM 1983 Resting human female breast tissue produces iodinated proteins. Journal of Ultrastructure Research 84 130-139.

Takamatsu J, Hosoya T, Tsuji M, Yamada M, Murakami Y, Sakane S, Kuma K \& Ohsawa N 1992 Peroxidase and coupling activities of thyroid peroxidase in benign and malignant thyroid tumor tissues. Thyroid 2 193-196.

Taki K, Kogai T, Kanamoto Y, Hershman JM \& Brent GA 2002 A thyroid-specific far-upstream enhancer in the human sodium/iodide symporter gene requires Pax-8 binding and cyclic adenosine $3^{\prime}, 5^{\prime}$-monophosphate response element-like sequence binding proteins for full activity and is differentially regulated in normal and thyroid cancer cells. Molecular Endocrinology 16 2266-2282.

Tanaka K, Inoue H, Miki H, Masuda E, Kitaichi M, Komaki K, Uyama T \& Monden Y 1997 Relationship between prognostic score and thyrotropin receptor (TSH-R) in papillary thyroid carcinoma: immunohistochemical detection of TSH-R. British Journal of Cancer 76 594-599.

Tanosaki S, Ikezoe T, Heaney A, Said JW, Dan K, Akashi M \& Koeffler HP 2003 Effect of ligands of nuclear hormone receptors on sodium/iodide symporter expression and activity in breast cancer cells. Breast Cancer Research and Treatment 79 335-345.

Tazebay UH, Wapnir IL, Levy O, Dohan O, Zuckier LS, Zhao QH, Deng HF, Amenta PS, Fineberg S, Pestell RG et al. 2000 The mammary gland iodide transporter is expressed during lactation and in breast cancer. Nature Medicine 6 871-878.

Tell G, Pellizzari L, Cimarosti D, Pucillo C \& Damante G $1998 a$ Ref-1 controls pax-8 DNA-binding activity. Biochemical and Biophysical Research Communications 252 178-183.

Tell G, Scaloni A, Pellizzari L, Formisano S, Pucillo C \& Damante G 1998b Redox potential controls the structure and DNA binding activity of the paired domain. Journal of Biological Chemistry 273 25062-25072.

Tell G, Pellizzari L, Pucillo C, Puglisi F, Cesselli D, Kelley MR, Di Loreto C \& Damante G 2000 TSH controls Ref-1 nuclear translocation in thyroid cells. Journal of Molecular Endocrinology 24 383-390.

Thibonnier M, Berti-Mattera LN, Dulin N, Conarty DM \& Mattera R 1998 Signal transduction pathways of the human V1-vascular, V2-renal, V3-pituitary vasopressin and oxytocin receptors. Progress in Brain Research 119 147-161.

Thorpe SM 1976 Increased uptake of iodide by hormoneresponsive compared to hormone-independent mammary tumors in GR mice. International Journal of Cancer $\mathbf{1 8}$ 345-350.

Trapasso F, Iuliano R, Chiefari E, Arturi F, Stella A, Filetti S, Fusco A \& Russo D 1999 Iodide symporter gene expression in normal and transformed rat thyroid cells. European Journal of Endocrinology 140 447-451.

Tsygankova OM, Saavedra A, Rebhun JF, Quilliam LA \& Meinkoth JL 2001 Coordinated regulation of Rap1 and thyroid differentiation by cyclic AMP and protein kinase A. Molecular and Cellular Biology 21 1921-1929.

Tubiana M, Haddad E, Schlumberger M, Hill C, Rougier P \& Sarrazin D 1985 External radiotherapy in thyroid cancers. Cancer 55 2062-2071.

Tyler DS, Shaha AR, Udelsman RA, Sherman SI, Thompson NW, Moley JF \& Evans DB 2000 Thyroid cancer: 1999 update. Annals of Surgical Oncology 7 376-398.

Upadhyay G, Singh R, Agarwal G, Mishra SK, Pal L, Pradhan PK, Das BK \& Godbole MM 2003 Functional expression of sodium iodide symporter (NIS) in human breast cancer tissue. Breast Cancer Research and Treatment 77 157-165.

Valenta L 1966 Metastatic thyroid carcinoma in man concentrating iodine without organification. Journal of Clinical Endocrinology and Metabolism 26 1317-1324.

Vandeput F, Perpete S, Coulonval K, Lamy F \& Dumont JE 2003 Role of the different mitogen-activated protein kinase subfamilies in the stimulation of dog and human thyroid epithelial cell proliferation by cyclic adenosine $5^{\prime}$ monophosphate and growth factors. Endocrinology 144 1341-1349.

Venkataraman GM, Yatin M \& Ain KB 1998 Cloning of the human sodium-iodide symporter promoter and characterization in a differentiated human thyroid cell line, KAT-50. Thyroid 8 63-69.

Venkataraman GM, Yatin M, Marcinek R \& Ain KB 1999 Restoration of iodide uptake in dedifferentiated thyroid carcinoma: relationship to human $\mathrm{Na}+/ \mathrm{I}-$ symporter gene methylation status. Journal of Clinical Endocrinology and Metabolism 84 2449-2457.

Venkateswaran A, Marsee DK, Green SH \& Jhiang SM 2004 Forskolin, 8-Br- $3^{\prime}, 5^{\prime}$-cyclic adenosine $5^{\prime}$-monophosphate, and catalytic protein kinase $\mathrm{A}$ expression in the nucleus increase radioiodide uptake and sodium/iodide symporter protein levels in RET/PTC1-expressing cells. Journal of Clinical Endocrinology and Metabolism 89 6168-6172.

Vinson C, Myakishev M, Acharya A, Mir AA, Moll JR \& Bonovich M 2002 Classification of human B-ZIP proteins based on dimerization properties. Molecular and Cellular Biology 22 6321-6335.

Vuligonda V, Thacher SM \& Chandraratna RA 2001 Enantioselective syntheses of potent retinoid $\mathrm{X}$ 
receptor ligands: differential biological activities of individual antipodes. Journal of Medicinal Chemistry 44 2298-2303.

Wapnir IL, van de Rijn M, Nowels K, Amenta PS, Walton K, Montgomery K, Greco RS, Dohan O \& Carrasco N 2003 Immunohistochemical profile of the sodium/iodide symporter in thyroid, breast, and other carcinomas using high density tissue microarrays and conventional sections. Journal of Clinical Endocrinology and Metabolism $\mathbf{8 8}$ 1880-1888.

Wapnir IL, Goris M, Yudd A, Dohan O, Adelman D, Nowels $\mathrm{K} \&$ Carrasco N 2004 The $\mathrm{Na}+/ \mathrm{I}-$ symporter mediates iodide uptake in breast cancer metastases and can be selectively down-regulated in the thyroid. Clinical Cancer Research 10 4294-4302.

Ward LS, Santarosa PL, Granja F, da Assumpcao LV, Savoldi M \& Goldman GH 2003 Low expression of sodium iodide symporter identifies aggressive thyroid tumors. Cancer Letters 200 85-91.

Weiss SJ, Philp NJ, Ambesi-Impiombato FS \& Grollman EF $1984 a$ Thyrotropin-stimulated iodide transport mediated by adenosine $3^{\prime}, 5^{\prime}$-monophosphate and dependent on protein synthesis. Endocrinology 114 1099-1107.

Weiss SJ, Philp NJ \& Grollman EF 1984b Iodide transport in a continuous line of cultured cells from rat thyroid. Endocrinology 114 1090-1098.

Welcsh PL \& Mankoff DA 2000 Taking up iodide in breast tissue. Nature 406 688-689.
Xu J, Kogai T, Brent GA \& Hershman JM 2002 A GC box in the human sodium iodide symporter gene promoter is essential for full activity. Thyroid 12 107-114.

Yoshida A, Taniguchi S, Hisatome I, Royaux IE, Green ED, Kohn LD \& Suzuki K 2002 Pendrin is an iodide-specific apical porter responsible for iodide efflux from thyroid cells. Journal of Clinical Endocrinology and Metabolism 87 3356-3361.

Yoshida A, Hisatome I, Taniguchi S, Sasaki N, Yamamoto Y, Miake J, Fukui H, Shimizu H, Okamura T, Kura J et al. 2004 Mechanism of iodide/chloride exchange by pendrin. Endocrinology 145 4301-4308.

Zannini M, Francis-Lang H, Plachov D \& Di Lauro R 1992 Pax-8, a paired domain-containing protein, binds to a sequence overlapping the recognition site of a homeodomain and activates transcription from two thyroidspecific promoters. Molecular and Cellular Biology 12 4230-4241.

Zarnegar R, Brunaud L, Kanauchi H, Wong M, Fung M, Ginzinger D, Duh QY \& Clark OH 2002

Increasing the effectiveness of radioactive iodine therapy in the treatment of thyroid cancer using Trichostatin A, a histone deacetylase inhibitor. Surgery 132 984-990.

Zheng T, Holford TR, Mayne ST, Luo J, Owens PH, Zhang B, Zhang W \& Zhang Y 2002 Radiation exposure from diagnostic and therapeutic treatments and risk of breast cancer. European Journal of Cancer Prevention 11 229-235. 